\title{
O ENTRAVE DA RESERVA DO POSSÍVEL NO CAMINHO RUMO À EFETIVAÇÃO DOS DIREITOS FUNDAMENTAIS SOCIAIS
}

FUNDAMENTAL SOCIAL RIGHTS: THE WAY OF EFETIVATION AND POSSIBLE RESERVE

\section{Neurilene Gomes da Silva}

\begin{abstract}
Resumo:
Este trabalho tem por escopo principal estudar o atual desafio da efetivação dos direitos fundamentais sociais de cunho prestacional. Busca demonstrar com realce que os direitos sociais foram incluídos na Constituição Federal como cerne de todo o ordenamento jurídico. Portanto servem de parâmetro para a atuação de todos os entes que compõem o Estado. Deveras, tais direitos estão ligados a conflitos oriundos da esfera social, tendo em vista as imensas e gritantes desigualdades da sociedade brasileira. Todavia, não deve haver o desvirtuamento dos objetivos do Estado estabelecidos em sua Lei Maior, apenas com supedâneo no argumento do instituto da reserva do possível, sem o ônus argumentativo do Poder Público que, deverá comprovar de forma consistente a ausência ou insuficiência de recursos Públicos para a concretização de determinado direito social pleiteado perante o Judiciário.

Palavras-chave: Direitos fundamentais sociais. Efetivação. Reserva do possível. Mínimo existencial. Princípio da proporcionalidade.
\end{abstract}

\begin{abstract}
:
This work has as main purpose to study the current challenge of enforcement of fundamental social nature of prestacional. Seeks to demonstrate to highlight that social rights were included in the Federal Constitution as the core of the whole legal system. So are a parameter for the performance of all entities that comprise the state. Indeed, such rights are linked to conflicts arising from the social sphere, in view of the huge and glaring inequalities of Brazilian society. However, there should be no distortion of the goals of the State established in its highest law, only with footstool in the argument of the Office of the reservation as possible, without the burden of argument that the Government should consistently demonstrate the absence or insufficiency of funds public resources for achieving of certain social legislation pleaded before the courts.
\end{abstract}

Keywords: Fundamental social rights. Completion. Book possible. Minimum existential principle of proportionality.

\section{Evolução e positivação dos Direitos Sociais no Brasil}

Preliminarmente, vale ressaltar que os direitos fundamentais em sua origem eram tidos como direitos naturais do homem até a sua positivação nas constituições. Merecem ênfase inclusive sob a perspectiva internacional, visto haver sua configuração

- Bacharel em Direito pela Universidade Mogi das Cruzes; Pós-graduanda em Direito Processual Civil e Trabalhista pela Escola Paulista de Direito. Servidora da Faculdade de Direito da Universidade de São Paulo. A Autora teve o trabalho indicado pelo Professor Titular Rubens Beçak, Secretário Geral da Universidade de São Paulo. 
também como direitos humanos, sendo sua finalidade básica, conforme leciona Anderson Vaz, o respeito à dignidade humana, preservando-a contra a ação arbitrária do Estado, assegurando para tanto condições mínimas de vida humana digna que exigem prestações estatais positivas. ${ }^{1}$

Rosalia Carolina Kappel Rocha, membro da Advocacia Geral da União, entende que:

Quanto ao aspecto histórico, releva notar que os direitos fundamentais têm origem no surgimento do moderno Estado Constitucional, cuja essência e razão de ser residem no reconhecimento e na proteção da dignidade da pessoa humana e dos direitos fundamentais do homem. Assim, pode-se afirmar que a história dos direitos fundamentais está ligada à história da limitação do poder. ${ }^{2}$

$\mathrm{Na}$ esteira dos ensinamentos do professor Ingo Wolfgang Sarlet, percebese que, historicamente os direitos fundamentais têm origem no surgimento do moderno Estado Constitucional, cuja essência e razão de ser residem no reconhecimento e na proteção da dignidade da pessoa humana e dos direitos fundamentais do homem. Assim, pode-se afirmar que a história dos direitos fundamentais está ligada à história da limitação do poder. ${ }^{3}$

Quanto à evolução dos direitos fundamentais, interessa frisar que não é linear e sobre eles deve ser feita uma leitura sob a perspectiva histórica, visto que fluem de acordo com os fatores sociais de determinado tempo e espaço.

O Ministro do Supremo Tribunal Federal, Enrique Ricardo Lewandowski observa:

É importante registrar, no entanto, que, embora desenvolvidos ao longo de várias gerações, não existe hierarquia entre os direitos humanos em função dessa cronologia. Todos eles têm o mesmo valor e são indivisíveis, pois não se pode dissociar, por exemplo, o direito à vida e à liberdade, que são de primeira geração, do direito a uma vida e liberdade digna, que só se materializam por meio de direitos de segunda e terceira geração. ${ }^{4}$

VAZ, Anderson. A cláusula da reserva do financeiramente possivel como instrumento de efetivação planejada dos direitos humanos econômicos, sociais e culturais. Revista de Direito Constitucional e Internacional, ano 17, jan/mar, 2009, n. 66.

2 ROCHA, Rosalia Carolina Kappel. A eficácia dos direitos sociais e a reserva do possivel. Disponível em $<$ http://www.escola.agu.gov.br/revista/Ano_V_novembro_2005/rosalia-eficacia.pdf $>$. Acesso em: 05 jul. 2010.

3 SARLET, Ingo Wolfgang. A eficácia dos direitos fundamentais. 3. ed. rev. e atual. Porto Alegre: Livraria do Advogado, 2003. p. 39.

4 LEWANDOWSKI, Enrique Ricardo. A formação da doutrina dos direitos fundamentais. Revista da Faculdade de Direito da Universidade de São Paulo, v. 98, jan./dez. 2003, p.411-422. 
Os direitos fundamentais sociais representam a segunda dimensão dos direitos fundamentais, denominados direitos econômicos, culturais e sociais, dentre os quais, neste trabalho tratar-se-á especificamente como direitos sociais, mormente no que tange ao seu processo de implementação, frente à alegação da reserva do possivel.

Consoante leciona o jurista Norberto Bobbio:

Finalmente foram proclamados os direitos sociais, que expressam o amadurecimento de novas exigências podemos mesmo dizer, de novos valores - como os do bemestar e da igualdade não apenas formal, e que poderíamos chamar de liberdade através ou por meio do Estado. ${ }^{5}$

Ressalte-se que a conquista dos direitos fundamentais é fruto de lutas ao longo da história, acumuladas gradativamente, sendo sua positivação decorrente de suportes fáticos diversos, os quais desaguaram em documentos ${ }^{6}$ que, hoje são marcos históricos dos direitos fundamentais no Brasil e no mundo.

Impende ressaltar, na seara desta temática, foco central da presente pesquisa que, segundo ensinamento do professor Ingo Wolfgang Sarlet:

(...) os direitos a prestações objetivam, em última análise, a garantia não apenas da liberdade-autonomia (liberdade perante o Estado), mas também da liberdade por intermédio do Estado, partindo da premissa de que o indivíduo, no que concerne à aquisição e manutenção de sua liberdade, depende em muito de uma postura ativa dos poderes públicos. ${ }^{\top}$

Os direitos fundamentais transformaram-se em garantias do homem em face do Estado soberano. Atualmente, não mais apenas em face do Estado, como também perante a própria sociedade. ${ }^{8}$

BOBBIO, Norberto. A era dos direitos. Rio de Janeiro: Editora Elsevier, 2004, p.52.

- Sob esta perspectiva ver a DUDH Declaração Universal dos Direitos Humanos de 1948, o PIDESC Pacto Internacional de Direitos Econômicos, Sociais e Culturais de 1966 - ratificado pelo Brasil em 1992, e a Convenção Americana sobre Direitos Humanos (Pacto São José da Costa Rica) de 1969 - ratificada pelo Brasil em 1992.

7 SARLET, Ingo Wolfgang. Os direitos fundamentais sociais na Constituição de 1988. Revista Diálogo Jurídico, ano I, v. 1, 2001. Disponivel em <http://www.direitopublico.com.br/pdf_seguro/REVISTADIALOGO-JURIDICO-01-2001-INGO-SARLET.pdf> Acesso em 20/09/2010.

8 Conforme leciona o juiz federal Luiz Alberto Gurgel de Faria: "Os movimentos socialistas surgidos na Europa, a partir do século XIX, também vieram em defesa de melhores condições de vida para as pessoas, forçando uma reflexão acerca do pensamento então dogmatizado - laissez faire, laissez passer... Origina-se, pois, o Welfare State, cuja preocupação primeira passa a ser o bem-estar social da coletividade. A mudança de compreensão da função estatal força o reconhecimento, por aquela entidade político-administrativa, dos direitos sociais, com o início do processo de positivação dessas prerrogativas. A primeira Constituição político-social do mundo foi instituída pelo México, em 1917, seguida, logo após, pela da Alemanha, em 1919. No Brasil, a Carta Política de 1934 inaugurou a fase do constitucionalismo social, o que foi observado nos textos seguintes: 1937, 1946, 1967/69 e 1988" In: FARIA, Alberto Gurgel de. Direitos sociais: positivação x eficácia. Disponivel em: $<$ http://www.buscalegis.ufsc.br/revistas/index.php/buscalegis/article/ 
Segundo o jurista Norberto Bobbio:

O problema fundamental em relação aos direitos do homem, hoje, não é tanto o de justificá-los, mas o de protegê-los. Trata-se de um problema não filosófico, mas político. (...) Com efeito, o problema que temos diante de nós não é filosófico, mas jurídico e, num sentido mais amplo, político. Não se trata de saber quais e quantos são esses direitos, qual a sua natureza e seu fundamento, se são direitos naturais ou históricos, absolutos ou relativos, mas sim qual é o modo mais seguro para garanti-los, para impedir que, apesar das solenes declarações, eles sejam continuamente violados. ${ }^{9}$

Convém, neste ponto, conceituar os direitos fundamentais sociais que, segundo ensinamentos do constitucionalista José Afonso da Silva:

(...) são prestações positivas proporcionadas pelo Estado direta ou indiretamente, enunciadas em normas constitucionais, que possibilitem melhores condições de vida aos mais fracos, direitos que tendem a realizar a igualização de situações sociais desiguais. São, portanto, direitos que se ligam ao direito da igualdade. ${ }^{10}$

Os direitos fundamentais sociais são garantias, direitos a prestações, a condições materiais mínimas, básicas à existência com dignidade, pois inerente à própria condição humana está o direito a uma vida condigna.

\section{Segundo observa o professor Fernando Facury Scaff:}

(...) nos países periféricos onde a situação socioeconômica acarreta amplas desigualdades sociais, com déficits de condição econômica para grande parte da população, há de haver uma estreita vinculação entre a teoria do mínimo existencial (status positivus libertatis) e os direitos fundamentais sociais. Este fator não invalida a tese de Ricardo Lobo Torres conforme exposta na parte inicial deste trabalho, mas apenas coloca diferenciais de sua aplicabilidade e enfoque para países que se encontram na periferia do capitalismo, como o Brasil. ${ }^{11}$

E segue na mesma linha de raciocínio o professor supramencionado:

viewFile/15592/15156>. Acesso em: 19 set. 2010.

9 BOBBIO, Norberto. A era dos direitos. Rio de Janeiro: Editora Campus, 1992. p. $24-25$.

10 SILVA, José Afonso da. Direito constitucional positivo. 27. ed. rev. e atual. São Paulo: Malheiros, 2006. p. 286-287.

"SCAFF, Fernando Facury. Reserva do possível, mínimo existencial e direitos humanos. Revista Interesse Público, n. 32, p. 213-226, 2005. Disponivel em: http://www.scaff.adv.br/cgi-bin/lista_doc.cgi?id_usuario= $1000001 \& u=1000000 \& \mathrm{~d}=19 \& \mathrm{dt}=20080512 \& \mathrm{c}=0 \& \mathrm{fl} \_$backup $=0 \&$ data_backup $=($ null $)$. Acesso em: 09 ago. 2010. 
A aplicação dos direitos fundamentais sociais decorre da necessidade de dotar esta parcela da população excluida dos patamares mínimos de condições para o exercício de suas capacidades, ou, por outras palavras, de condiçôes para realizar a liberdade real a fim de poder gozar da liberdade jurídica (Robert Alexy). Sem tais condições reais (fáticas) para o exercício da liberdade jurídica, esta se tornará letra morta. $^{12}$

Outrossim, salienta o mestre das Arcadas José Afonso da Silva: "Valem como pressupostos dos direitos individuais na medida em que criam condições materiais mais propícias ao auferimento da igualdade real, o que, por sua vez, proporciona a condição mais compatível com o exercício efetivo da liberdade" 13

Assevera o jurista Norberto Bobbio:

O campo dos direitos sociais está em contínuo movimento: assim como as demandas de proteção social nasceram com a revolução industrial, é provável que o rápido desenvolvimento técnico e econômico traga consigo novas demandas, que hoje não somos capazes nem de prever. ${ }^{14}$

Os direitos sociais não englobam apenas direitos de cunho positivo, mas também as liberdades sociais de cunho negativo ou direitos sociais de defesa. À guisa de ilustração, tem-se a liberdade de sindicalização, o direito de greve, a garantia de saláriomínimo, limitação de jornada de trabalho, entre outros. ${ }^{15}$

Acerca da teoria da reserva do possível Fernando Facury Scaff observa que esta encontra-se:

(...) condicionada pelas disponibilidades orçamentárias, porém os legisladores não possuem ampla Liberdade de Conformação, pois estão vinculados ao Princípio da Supremacia Constitucional, devendo implementar os objetivos estabelecidos na Constituição de 1988, que se encontram no art. $3^{\circ}$ dentre outras normas-objetivo. Esta teoria somente pode ser arguida quando for comprovado que os recursos públicos estão sendo utilizados de forma proporcional aos problemas enfrentados pela parcela da população que não puder exercer sua liberdade jurídica, e de modo progressivo no tempo, em face de não conseguir a liberdade real necessária para tanto (Robert Alexy), ou não

12 Id. Ibid.

13 SILVA, José Afonso da. Garantias econômicas, politicas e juridicas da eficácia dos direitos sociais. Disponivel em: <http://www.mundojuridico.adv.com.br>. Acesso em: 07 ago 2010.

14 BOBBIO, Norberto. A era dos direitos. Rio de Janeiro: Editora Elsevier, 2004. p. 51.

15 SARLET, Ingo Wolfgang. A eficácia dos direitos fundamentais. 3. ed. rev. e atual. Porto Alegre: Livraria do Advogado, 2003. p. 53. 
puder exercer suas capacidades para exercer tais liberdades. Tal procedimento não implica judicialização da política ou ativismo judicial, pois se trata apenas de aplicação da Constituição brasileira. ${ }^{16}$

Consoante observação de Érica Pessanha, acerca da ineficiência do Estado Liberal no que diz respeito à eficácia dos direitos sociais:

Com o passar do tempo, as fraquezas do Estado Liberal tornaram-se latentes e facilmente identificadas. A industrialização gerou um quadro crítico de miséria humana e de superexploração da mão-de-obra, demonstrando que os ideais burgueses haviam contribuído para a construção de um capitalismo selvagem e comprometido em demasia a dignidade humana. ${ }^{17}$

Nesta quadra da exposição, cabível enfatizar que os primeiros direitos fundamentais incorporados pelas constituições são denominados de primeira dimensão. Dizem respeito à vida, à liberdade, à propriedade e à igualdade perante a lei, delimitando dessa forma a chamada igualdade formal. Em seguida, vêm as liberdades coletivas (de expressão, de imprensa, de reunião, de associação, dentre outras); os direitos de participação política, como o direito de voto e a capacidade eleitoral passiva; e também algumas garantias processuais: devido processo legal, direito de petição e habeas corpus. Alerta o professor Ingo Wolfgang Sarlet:

Hoje, somos, em verdade, o campo de batalha onde se confrontam um sem-número de segmentos corporativos que buscam "mostrar serviço" de modo anárquico e disfuncional, pretendendo, com isso, justificar os privilégios que se atribuíram e querem ser mantidos. Assim, em nosso país, aos problemas que enfrentam os países sociais democratas somamos o irrealismo com que constitucionalizamos a nossa realidade, talvez na ingênua crença de que se pode juridicizar a convivência humana sem maior preocupação de fazê-lo em harmonia com o que ela é na faticidade do social. $^{18}$

16 SCAFF, Fernando Facury. Reserva do possível, mínimoexistencial e direitos humanos. Revista Interesse Público, n. 32, p. 213-226, 2005. Disponível em http://www.scaff.adv.br/cgi- bin/lista_doc.cgi?id_usuar $\mathrm{io}=1000001 \& \mathrm{u}=1000000 \& \mathrm{~d}=19 \& \mathrm{dt}=20080512 \& \mathrm{c}=0 \& \mathrm{fl} \_$backup=0\&data_backup $=($null). . Acesso $\mathrm{em}$ 09/08/2010.

17 PESSANHA, Érica. A eficácia dos direitos sociais prestacionais. Disponivel em: <http://www.buscalegis. ufsc.br/revistas/index.php/buscalegis/article/viewFile/32796/31991<http://bdjur.stj.gov.br/xmlui/ handle/2011/24792>. Acesso em: 04 jul. 2010.

18 SARLET, Ingo Wolfgang. A eficácia dos direitos fundamentais. 3. ed. rev. e atual. Porto Alegre: Livraria do Advogado, 2003. p.53. 
Posteriormente, como fruto dos movimentos reivindicatórios que exigiam do Estado uma atuação efetiva na realização da justiça social, vieram os direitos de segunda dimensão, que são os direitos econômicos, sociais e culturais. Consoante observa Elmo José Duarte de Almeida Júnior, os direitos fundamentais sociais possuem ampla conexão com o direito à igualdade. ${ }^{19}$

No tocante à dificuldade de efetivação dos direitos fundamentais sociais, válido assinalar; consoante leciona Anderson Orestes Cavalcante Lobato, que:

As normas constitucionais definidoras dos direitos sociais, econômicos e culturais, desde suas primeiras experiências

Constituição mexicana de 1917 e, particularmente a Constituição alemã, de Weimar, de 1919 encontram dificuldades de aceitação e implementação. Com efeito, neste momento busca-se romper com constitucionalismo liberal individualista, para ingressarmos numa nova fase da história das constituições no ocidente, o constitucionalismo social. ${ }^{20}$

O mestre constitucionalista Ingo Wolfgang Sarlet classifica os direitos fundamentais sociais em dois grupos: direitos negativos ou direitos de defesa e direitos positivos ou direitos a prestações. ${ }^{21}$

Note-se que no primeiro aspecto, os direitos fundamentais constituemse em "direitos de defesa do indivíduo contra ingerências do Estado em sua liberdade pessoal e propriedade" Enquanto que sob a segunda dimensão encontram-se os direitos fundamentais sociais prestacionais. ${ }^{22}$

Outrossim, nessa linha de pensamento, o professor prossegue afirmando que:

(...) acima de tudo, os direitos fundamentais na condição de direitos de defesa - objetivam a limitação do poder estatal, assegurando ao indivíduo uma esfera de liberdade e lhe outorgando um direito subjetivo que lhe permita evitar interferências indevidas no âmbito da proteção do direito

19 ALMEIDA, Elmo José Duarte de Almeida Júnior. Aspectos relevantes dos direitos sociais de prestação frente ao mínimo existencial e à reserva possivel. Disponível em: <http://jus2.uol.com.br/doutrina/texto. asp?id=10357>. Acesso em: 10 ago. 2010.

20 LOBATO, Anderson Orestes Cavalcante. Os desafios da proteção jurisdicional dos direitos sociais, econômicos e culturais. Disponível em: $<\mathrm{http} / /$ www.dhnet.org.br/direitos/textos/textos_dh/protjurisd_desc. $\mathrm{htm}>$. Acesso em: 22 ago. 2010.

21 SARLET, Ingo Wolfgang. Os direitos fundamentais sociais na Constituição de 1988. Revista Diálogo Juridico, ano 1, v. 1, 2001. Disponivel em: <http://www.direitopublico.com.br/pdf_seguro/REVISTADIALOGO-JURIDICO-01-2001-INGO-SARLET.pdf > Acesso em: 20 ago. 2010.

22 SARLET, Ingo Wolfgang. Os direitos fundamentais sociais na Constituição de 1988. Revista Diálogo Juridico, ano l, v. 1, 2001. Disponível em: <http://www.direitopublico.com.br/pdf_seguro/REVISTADIALOGO-JURIDICO-01-2001-INGO-SARLET.pdf >. Acesso em: 20 set. 2010. 
fundamental ou mesmo a eliminação de agressões que esteja sofrendo em sua esfera de autonomia pessoal. ${ }^{23}$

Já no segundo plano, ou seja, os direitos sociais a prestações são:

(...) vinculados à concepção de que ao Estado incumbe, além da não intervenção na esfera de liberdade pessoal dos indivíduos, assegurada pelos direitos de defesa (ou função defensiva dos direitos fundamentais), a tarefa de colocar à disposição os meios materiais e implementar condições fáticas que possibilitam o efetivo exercício das liberdades fundamentais (...). ${ }^{24}$

E os direitos de terceira dimensão são considerados como direitos de solidariedade ou fraternidade, que, em face de sua implicação universal, ainda carecem de positivação em muitos países, isso porque exigem esforços e responsabilidades, em escala até mesmo global, para sua efetivação. ${ }^{25}$

Conforme adverte Érica Pessanha:

Somente a garantia de liberdades não era suficiente para proporcionar e promover a dignidade da pessoa humana; era necessário investir no bem-estar do indivíduo. Iniciase, então, através do nascimento do Estado Social ("welfare state"), a segunda geração ou dimensão dos direitos fundamentais, consagrada pelos direitos econômicos, sociais e culturais, cujo valor reside na igualdade.

Nesse passo, importa frisar que na seara da positivação dos direitos fundamentais sociais, a priori, é necessário que se faça o reconhecimento da real finalidade desses direitos, sua extensão e conseqüências históricas, com o fito de se fazer a melhor leitura do contexto atual e que se busquem constantemente as melhores soluções para as inúmeras necessidades humanas sociais. Pois, acima de tudo deve estar a finalidade maior do país, insculpida na Constituição Federal da República de 1988, que é a busca do bemestar social, conforme se pode observar ao longo do texto constitucional.

Érica Pessanha sustenta que:

Quanto à positivação destes direitos, pode-se dizer que ocorreu a partir da Primeira Guerra Mundial com a Constituição Mexicana de 1917, a Declaração dos Direitos do Povo Trabalhador e Explorado da então União Soviética,

23 SARLET, Ingo Wolfgang. Os direitos fundamentais sociais na Constituição de 1988. Revista Diálogo Juridico, ano 1, v. 1, 2001. Disponivel em: <http://www.direitopublico.com.br/pdf_seguro/REVISTADIALOGO-JURIDICO-01-2001-INGO-SARLET.pdf>. Acesso em: 20 set. 2010.

${ }^{24}$ Id. Ibid.

${ }_{25}$. A eficácia dos direitos fundamentais. 3. ed. rev. e atual. Porto Alegre: Livraria do Advogado, 2003. p. 53 . 
em 1918, e a Constituição de Weimar de 1919. No Brasil, foi a Carta de 1934 que realmente inaugurou a fase do constitucionalismo social no país, dedicando um título exclusivo à ordem econômica e social, iniciando a era da intervenção estatal. ${ }^{26}$

Neste cenário, no que diz respeito às inovações trazidas pela Constituição de 1988, na esteira dos ensinamentos de Ana Carolina Lopes Olsen, essencial frisar:

(...) o enquadramento de uma série de direitos antes relegados

à ordem social e econômica como autênticos direitos fundamentais: os chamados direitos fundamentais sociais. Com isso, buscou evidenciar a desigualdade econômica que marca a sociedade brasileira, bem como atribuir direitos que contemplassem todos os cidadãos de modo a lhes garantir condições dignas de sobrevivência e participação nos processos democráticos. É o que se depreende, por exemplo, do artigo $6^{\circ}$ da Constituição, segundo o qual todos têm direito à educação, à saúde, à moradia, à assistência social, à previdência, ao lazer. ${ }^{27}$

Ademais, releva notar que o Brasil avançou no reconhecimento e inclusão na sua agenda pública de inúmeros problemas sociais. São necessidades e problemas intrínsecos à vida humana e coletiva e, por este motivo, seu enfrentamento ocorre por meio dos direitos fundamentais sociais.

Nesse contexto, cumpre salientar que os direitos sociais a prestações, diversamente dos direitos de defesa, não se dirigem à proteção da liberdade e igualdade abstrata, mas, sim, encontram-se intimamente vinculados às tarefas de melhoria, de distribuição e redistribuição dos recursos existentes, assim como à criação de bens essenciais não disponíveis para todos os que dele necessitam, ou seja, relacionam-se com a liberdade real e com a igualdade material. ${ }^{28}$

Topograficamente, na Constituição Federal de 1988, os direitos fundamentais sociais têm um capítulo dedicado a eles, visto sua grande relevância. Especificamente, os direitos de segunda dimensão ou direitos econômicos, sociais e culturais localizam-se no Capítulo II do Título II que trata dos direitos e garantias fundamentais, sendo que o primeiro capítulo deste título traz os direitos e garantias individuais direitos de primeira dimensão.

26 PESSANHA, Érica. A eficácia dos direitos sociais prestacionais. Disponível em: <http://bdjur.stj.gov.br/ xmlui/handle/2011/24792>. Acesso em: 20 ago. 2010.

27 OLSEN, Ana Carolina Lopes. A eficácia dos direitos fundamentais sociais frente à reserva du possivel. Dissertação apresentada na UFPR, 2006. Disponivel em: <http://dspace.c3sl.ufpr.br/dspace/ bitstream/1884/3084/1/Disserta\%C3\%A7\%C3\%A30\%20\%20Ana\%20Carolina\%20Lopes\%20Olsen.pdf. Acesso em: 20 set. 2010.

28 SARLET, Ingo Wolfgang. A eficácia dos direitos fundamentais. cit., p.274. 
A título ilustrativo do contexto deste trabalho, vale lembrar que no bojo do artigo sexto o legislador Constituinte elencou como direitos sociais: a educação, a saúde, a alimentação, o trabalho, a moradia, o lazer, a segurança, a previdência social, a proteção à maternidade e à infância, a assistência aos desamparados. ${ }^{29}$

Frise-se que, além destes direitos fundamentais sociais que constam no extenso rol que compõe o catálogo disposto no artigo sexto da Constituição Federal, há o reconhecimento de outros elencados no artigo sétimo e ao longo da Constituição pátria de forma esparsa, bem como em tratados internacionais ratificados pelo Brasil, dos quais merece menção o PIDESC - Pacto Internacional dos Direitos Econômicos, Sociais e Culturais de 1966 - e ratificado pelo Brasil em 1992.

O constitucionalista Ingo Wolfgang Sarlet sustenta que os direitos sociais de cunho prestacional encontram-se a serviço da igualdade e da liberdade material, objetivando, em última análise, a proteção da pessoa frente às necessidades de ordem material e à garantia de uma existência com dignidade..$^{30}$

Nesse mesmo sentido, o professor supracitado entende que o princípio da igualdade, consagrado na Constituição Federal de 1988 é básico, essencial a todos, por força da própria condição humana. Está intrinsicamente associada à dignidade, que deve ser posta a salvo de qualquer limitação inviabilizadora de seu exercício. ${ }^{31}$

Outrossim, consoante leciona o jurista do Estado da Bahia Calmon Passos "nossa Constituição cidadã foi generosa ao enunciar direitos fundamentais, mas demasiadamente mesquinha, cautelosa e astuta no "assegurar esses direitos" Observa ainda o autor:

E isso porque o exercício do poder político, no Brasil, é algo que escapa a todo e qualquer controle social pelos governados. Não só em suas manifestações mais eminentes, de cúpula, como por igual na prática dos agentes situados nos últimos degraus da hierarquia dos que, na terra de Macunaíma, são "autoridades". Mais grave, ainda: por força da fragilidade política do povo de natureza fragmentária de nossa sociedade, organizamo-nos como um arquipélago de "autonomias", todos querendo ser suseranos, assumindo o compromisso moral, corporativo, de quitarmos os privilégios que pleiteamos e obtemos com nosso empenho

29 Nesse ensejo, tal dispositivo da Constituição de 1988 merece transcrição ipsis litteris: Art. $6^{\circ}$ São direitos sociais a educação, a saúde, a alimentação, o trabalho, a moradia, o lazer, a segurança, a previdência social, a proteção à maternidade e à infância, a assistência aos desamparados, na forma desta Constituição." (Redação dada pela recente Emenda Constitucional nº 64, de 2010).

30 SARLET, Ingo Wolfgang. A dignidade da pessoa humana e os direitos fundamentais na Constituição de 1988. Porto Alegre: Livraria do advogado, 2001. p. 92.

31 PASSOS, José Joaquim. Calmon de. A constitucionalização dos direitos sociais. Revista Diálogo Jurídico, Salvador, v. 1, n. 6, set. 2001. Disponível em: <http://www.direitopublico.com.br>. Acesso em: 20 jul. 2010. 
em tornarmos efetiva a cidadania de nossos vassalos, como se fosse possível transformar uma relação de dependências em relação de cidadania. ${ }^{32}$

Observe-se que a Constituição brasileira de 1988 é uma das mais avançadas do mundo em relação à proteção dos direitos humanos. Já em seu preâmbulo propõe o modelo de um Estado que assegure o exercício dos direitos sociais e individuais, $\mathbf{o}$ bemestar, a igualdade e a justiça como valores supremos da sociedade que se quer fraterna, pluralista e sem preconceitos.

Convém destacar que já no artigo $1^{\circ}$ da Constituição Federal de 1988 constam, nos incisos I e II respectivamente, entre os fundamentos do Estado brasileiro, a cidadania e a dignidade da pessoa humana, diretamente ligadas à satisfação das prestações objetos dos direitos fundamentais sociais.

Em seguida, a Lei Fundamental pátria, em seu artigo $3^{\circ}$ prescreve a construção de uma sociedade livre, justa e solidária no inciso I, erradicar a pobreza no inciso II, promover o bem de todos sem nenhum preconceito no inciso IV, como principais objetivos da República Federativa do Brasil. Portanto, o artigo $3^{\circ}$ funda como metas da sociedade e do Estado brasileiros a solidariedade, a erradicação da pobreza e da marginalização, bem como a redução das desigualdades sociais e regionais.

No que tange à positivação dos direitos fundamentais sociais, em que pese tal assertiva já frisada anteriormente, interessa salientar que o Constituinte originário os incluiu no capítulo II, como direitos fundamentais, portanto o parágrafo $1^{\circ}$ do artigo quinto abrange também os direitos sociais, haja vista que são autênticos direitos fundamentais.

Impende notar que os direitos em tela neste trabalho, representam uma busca pela igualdade social, pela igualdade material, isto ser um dos objetivos fundamentais da República Federativa do Brasil. ${ }^{33}$

Há que se ter em mira que, apenas a positivação não é suficiente para a efetivação de nenhum direito, mormente dos direitos fundamentais sociais, uma vez que estes reclamam não só o dever de abstinência, como também prestações positivas que satisfaçam as demandas sociais básicas.

$\mathrm{Na}$ esteira das lições do professor Ingo Wolfgang Sarlet, urge frisar que os direitos sociais abrangem tanto os direitos de cunho positivo quanto as liberdades sociais, as quais reclamam apenas uma abstenção por parte do Estado, não dependendo de

32 PASSOS, J. J. Calmon de. A constitucionalização dos direitos sociais. Revista Diálogo Jurídico, Salvador, v. 1, n. 6, set. 2001. Disponível em: <http://www.direitopublico.com.br>. Acesso em: 20 jul. 2010.

33 Art. $3^{\circ}$ Constituem objetivos fundamentais da República Federativa do Brasil:I - construir uma sociedade livre, justa e solidária;II garantir o desenvolvimento nacional;III - erradicar a pobreza e a marginalização e reduzir as desigualdades sociais e regionais; IV - promover o bem de todos, sem preconceitos de origem, raça, sexo, cor, idade e quaisquer outras formas de discriminação. 
alocação de recursos e de concretização legislativa para sua plena eficácia, como ocorre com os direitos sociais. ${ }^{34}$

No que diz respeito à subjetividade dos direitos fundamentais sociais, os autores Vitor França Dias Oliveira e Ari Ferreira Queiroz advertem:

(...) os direitos sociais são autênticos direitos subjetivos, inerentes ao espaço existencial do cidadão, o que se traduz na faculdade de se exigir dos entes públicos um determinado comportamento positivo (facere) ou negativo (non facere). Além desta dimensão subjetiva, intimamente ligada à idéia de prerrogativas, os direitos sociais, através das normas constitucionais que os consagram, apresentam sua dimensão subjetiva através de duas formas: 1) imposições legiferantes, as quais obrigam o legislador de atuar positivamente, criando as condições materiais e institucionais para o exercício de tais direitos e; 2) fornecimento de prestações, que se demonstram como a concretização da dimensão subjetiva. ${ }^{35}$

O professor Clèmerson Merlin Clève concebe o Judiciário como um poder contra majoritário, frente às falhas e omissões do Poder executivo e Poder Legislativo, em defesa dos direitos dos diversos grupos de minorias, sem educação, sem saúde, sem moradia etc.

De fato, no que diz respeito à atuação do juiz enquanto legislador negativo, para o jurista supramencionado há um consenso em favor da interferência do Judiciário.

Todavia, o mesmo não ocorre quando se está a falar numa atuação análoga à do legislador positivo; em outras palavras, em atuação semelhante à do administrador, no que tange à questão atinente ao Poder Judiciário intervir na esfera do Executivo. ${ }^{36}$

De outro viés, leciona o retrocitado doutrinador, interessa verificar a possibilidade de deduzir o impedimento para o juiz atuar a partir de determinado limite, por não possuir legitimação através do voto popular.

Poder-se-ia, eventualmente, afirmar, para afastar o argumento, que o Judiciário atua como uma espécie de delegado do Poder Constituinte para a defesa da Constituição e, especialmente, dos direitos fundamentais. O contra argumento basearse-ia no sentido de que, no contexto do regime democrático, é a maioria que governa, portanto a legitimidade seria apenas do Executivo e Legislativo. ${ }^{37}$

34 SARLET, Ingo Wolfgang. A eficácia dos direitos fundamentais. 9. ed. rev. e atual. Porto Alegre: Livraria do Advogado, 2008. p. 55, 292-294.

35 QUEIROZ, Ari Ferreira; OLIVEIRA, Vitor França Dias. A reserva do possivel como parâmetro de sindicância dos direitos fundamentais sociais. Disponivel em: <http://www.revistas.ufg.br/index.php/revfd/ article/viewArticle/9799>. Acesso em: 22 set. 2010.

36 CLĖVE, Clèmerson Merlin. A eficácia dos direitos sociais. Revista de Direito Constitucional e Internacional, São Paulo, ano 14, n. 54, jan./mar. 2006.

37 Id. Ibid. 
No tocante à efetividade do direito fundamental à saúde, um dos direito sociais mais peliteados perante o judiciário, leciona o professor Luís Roberto Barroso:

(...) alguém poderia supor, a um primeiro lance de vista, que se está diante de uma colisão de valores ou de interesses que contrapõe, de um lado, o direito à vida e à saúde e, de outro, a separação de Poderes, os princípios orçamentários e a reserva do possível. A realidade, contudo, é mais dramática. O que está em jogo, na complexa ponderação aqui analisada, é o direito à vida e à saúde de uns versus o direito à vida $\mathrm{e}$ à saúde de outros. Não há solução juridicamente fácil nem moralmente simples nessa questão. ${ }^{38}$

Ademais, conforme refere Luís Roberto Barroso:

$\mathrm{Na}$ prática, em todas as hipóteses em que a Constituição tenha criado direitos subjetivos - políticos, individuais, sociais ou difusos - são eles, como regra, direta e imediatamente exigíveis, do Poder Público ou do particular, por via das ações constitucionais e infraconstitucionais contempladas no ordenamento jurídico. O Poder Judiciário, como conseqüência, passa a ter papel ativo e decisivo na concretização da Constituição. ${ }^{39}$

Há autores que defendem a doutrina da plena eficácia dos direitos fundamentais sociais, denominada de doutrina da efetividade, que tem como fulcro sustentar que o direito constitucional é norma. Além desse método positivista, consoante leciona Luís Roberto Barroso, a doutrina da efetividade serviu-se de:

(...) um critério formal para estabelecer a exigibilidade de determinados direitos: se está na Constituição é para ser cumprido. Nos dias que correm, tornou-se necessária a sua convivência com novas formulações doutrinárias, de base pós-positivista, que levam em conta fenômenos apreendidos mais recentemente, como a colisão entre normas - especialmente as que abrigam princípios e direitos fundamentais -, a necessidade da ponderação para resolver tais situações, bem como conceitos como mínimo existencial. ${ }^{40}$

38 BARROSO, Luís Roberto. Da falta de efetividade à judicialização excessiva: direito à saúde, fornecimento gratuito de medicamentos e parâmetros para a atuação judicial. Disponível em: <www.Irbarroso.com.br/ $\mathrm{pt} /$ noticias/medicamentos.pdf $>$. Acesso em: 22 set. 2010.

39 BARROSO Luís Roberto. Da falta de efetividade à judicialização excessiva: direito à saúde, fornecimento gratuito de medicamentos e parâmetros para a atuação judicial. Disponível em: <www.lrbarroso.com.br/ pt/noticias/medicamentos.pdf $>$. Acesso em: 22 set. 2010.

40 BARROSO Luis Roberto. Da falta de efetividade à judicialização excessiva: direito à saúde, fornecimento gratuito de medicamentos e parâmetros para a atuação judicial. Disponivel em: <www. Irbarroso.com.br/ pt/noticias/medicamentos.pdf $>$. Acesso em: 22 set. 2010. 
Deveras, consoante afirma leciona o professor Luís Roberto Barroso ao ressaltar o inolvidável fato de que o Estado Constitucional de Direito gira em torno da dignidade da pessoa humana e da centralidade dos direitos fundamentais. E ressalta que a dignidade da pessoa humana é o centro de irradiação dos direitos fundamentais, sendo freqüentemente identificada como o núcleo essencial de tais direitos. ${ }^{41}$

2. A cláusula da reserva do possível - origem

Ao caminhar pela temática em foco, saliente-se que a cláusula da reserva do possível teve origem, em 1972, na doutrina alemã. O instituto nasceu no âmbito da decisão paradigmática da Corte Constitucional da Alemanha, no âmago do caso que ficou conhecido como numerus clausulus. ${ }^{42}$

Discutia-se no suprarreferido caso se era válido a limitação de vagas em universidades públicas, mais especificamente o acesso ao curso de medicina. Em que pese a Constituição alemã não ter positivado o direito à educação, a reivindicação pautava-se na liberdade de escolha profissional, consagrada na Constituição daquele país. Outrossim, questionava-se a compatibilidade com a Lei Fundamental, de certas regras legais estaduais que restringiam esse acesso ao ensino superior.

Note-se que o Tribunal alemão decidiu que a prestação exigida do Estado deve corresponder ao que o indivíduo pode razoavelmente exigir da sociedade, e entendeu que não seria razoável impor ao Estado a obrigação de acesso a todos os que pretendessem cursar medicina.

Conforme ensinamento oriundo do Superior Tribunal de Justiça, de lavra do Ministro Humberto Martins, extraído do recente Recurso Especial de número 1185474$\mathrm{SC}$ :

A tese da reserva do possível assenta-se em idéia que, desde
os romanos, está incorporada na tradição ocidental, no
sentido de que a obrigação impossível não pode ser exigida
(Impossibilium nulla obligatio est Celso, D. $50,17,185$ ).
Por tal motivo, a insuficiência de recursos orçamentários não

4) Id. Ibid..

42 Cf Ingo Wolfgang Sarlet: O conceito da reserva do possível surgiu de uma decisão paradigmática da Corte Constitucional Alemã (BVerfGE33, 303 (333), em que havia a pretensão de um cidadão de ingresso no ensino superior público, embora não existissem vagas suficientes. Tal reivindicação foi fundamentada na garantia da Lei Federal alemã de liberdade de escolha da profissão. Vale salientar que, nesta referida decisão, a Corte alemã afirma que a "prestação reclamada deve corresponder ao que o indivíduo pode razoavelmente exigir da sociedade, de tal sorte que, mesmo em dispondo o Estado dos recursos e tendo o poder de disposição, não se pode falar em uma obrigação de prestar algo que não se mantenha nos limites do razoável... Assim, poder-se-ia sustentar que não haveria como impor ao Estado a prestação de assistência social a alguém que efetivamente não faça jus ao benefício, por dispor, ele próprio, de recursos suficientes para seu sustento" (In SARLET, Ingo Wolfgang. A eficácia dos direitos fundamentais, 2001, p. 265). 
pode ser considerada uma mera falácia. Todavia, observase que a dimensão fática da reserva do possivel é questão intrinsecamente vinculada ao problema da escassez. Esta pode ser compreendida como "sinônimo" de desigualdade. ${ }^{4 j}$

Em que pese alguns autores continuarem a atribuir caráter programático aos direitos fundamentais sociais, há outros que negam sua subjetividade, em outras palavras, sua existência como direitos subjetivos. No entanto, quando se trata do direito à saúde, apenas questionam sua postulação jurídica de forma individual, diante dos possíveis reflexos negativos para a coletividade, alegando que os direitos fundamentais sociais têm caráter universal. ${ }^{44}$

No tocante à questão da aplicação imediata dos direitos sociais, o constitucionalista Ingo Wolfgang Sarlet defende esta tese, ao afirmar que o parágrafo primeiro do artigo $5^{\circ}$ da Constituição Federal ${ }^{45}$, que garante aplicação imediata às normas definidoras de direitos fundamentais, estende-se aos direitos sociais, pois estes também se inserem no Título II, que trata dos direitos e garantias fundamentais. ${ }^{46}$

Adverte o professor supramencionado, mesmo que tais normas não garantam um direito subjetivo ao titular, estes direitos gozarão sempre de certo grau de eficácia e aplicabilidade. ${ }^{47}$

\subsection{O instituto da reserva do possível no Brasil}

No Brasil, o caso paradigma em que se empregou o argumento da cláusula da reserva do possível foi a Arguição de Descumprimento de Preceito Fundamental ADPF 45/DF, cujo relator foi o Ministro Celso de Mello, em que houve o questionamento da legitimidade constitucional do controle e da intervenção do Poder Judiciário em tema de implementação de políticas públicas, quando configurada hipótese de abusividade governamental. ${ }^{48}$

43 STJ - REsp n. 1185474-SC. Min. Humberto Martins, j. 20/04/2010. Disponível<http://www.stj.jus.br/ $\mathrm{SCON} / \mathrm{jurisprudencia} /$ doc.jsp?livre $=$ reserva $+\mathrm{do}+$ possivel $\& \& b=\mathrm{ACOR} \& \mathrm{p}=$ true $\& \mathrm{t}=\& \mathrm{l}=10 \& \mathrm{i}=18>$ Acesso $18 / 08 / 2010$.

44 BARROSO, Luís Roberto. Da falta de efetividade à judicialização excessiva: direito à saúde, fornecimento gratuito de medicamentos e parâmetros para a atuação judicial. Disponivel <http://www.lrbarroso.com.br/ pt/noticias/medicamentos.pdf $>$. Acesso em: 16 out. 2010.

45 CF, Art. $5^{\circ} \S 1^{\circ}$ "As normas definidoras dos direitos e garantias fundamentais têm aplicação imediata.

46 SARLET, Ingo Wolfgang. A eficácia dos direitos fundamentais. Porto Alegre: Livraria do Advogado, 1998. p. 237.

47 Id. Ibid., p. 255.

48 STF, $A D P F$ n. 45 MC/DF- Med. Cautelar em ADPF, j. 29/04/2004. Disponivel em: <http://www.stf.jus.br/ portal/jurisprudencia/listarJurisprudencia.asp?sl=45. NUME.\&base=baseMonocraticas\%. Acesso em: 09 jul. 2010 . 
Nessa trilha, impende frisar que, há críticas quanto à transposição do instituto da reserva do possível pelo sistema brasileiro sem fazer as devidas adequações, visto que há grande diferença sócio-econômica entre os dois países: Brasil e Alemanha.

Observe-se que a autora constitucionalista Ana Carolina Lopes Olsen tece críticas à aplicação do instituto no Brasil, nos seguintes termos:

Verifica-se que no Brasil a doutrina da reserva do possível sofreu algumas modificações, não sendo aplicada exatamente nos mesmos termos em que foi desenvolvida na Alemanha. Ao que parece, a preocupação inicial com a proporcionalidade e a razoabilidade (aquilo que razoavelmente se pode exigir) deu lugar para a questão da disponibilidade de recursos, o custo dos direitos. (grifo nosso). ${ }^{49}$

Noutro giro, no âmbito da efetivação dos direitos sociais, cumpre realçar que a reserva do possível no Brasil, encontra-se intimamente imbricada com outras problemáticas, quais sejam o custo dos direitos e a escassez de recursos, alegadas em sede judicial pelo Poder Público quando instado à determinada prestação material, objeto de um direito fundamental social. ${ }^{50}$

O juiz federal George Marmelstein sustenta que:

O raciocínio que inspira o princípio da reserva do possível é inegavelmente econômico: implementar um direito à prestação exige a alocação de recursos, em maior ou menor quantidade, conforme o caso concreto, e, vale ressaltar, não apenas recursos financeiros, mas também recursos nãomonetários, como pessoal especializado e equipamentos. No entanto, há menos recursos do que o necessário para o atendimento de todas as demandas. ${ }^{51}$

No que concerne à escassez de recursos públicos, vale transcrição de trecho do Recurso Especial de número 1185474-SC de 2010, cujo Relator foi o Ministro Humberto Martins, que diz:

Bens escassos são bens que não podem ser usufruídos por todos e, justamente por isso, devem ser distribuídos

49 OLSEN, Ana Carolina Lopes. A eficácia dos direitos fundamentais sociais frente à reserva do possivel. Dissertação apresentada na UFPR, 2006. Disponivel em: <http://dspace.c3sl.ufpr.br/dspace/ bitstream $/ 1884 / 3084 / 1 /$ Disserta $\% C 3 \% A 7 \% C 3 \% A 30 \% 20 \% 20$ Ana $\% 20$ Carolina $\% 20$ Lopes $\% 20$ Olsen.pdf $>$. Acesso em: 20 set. 2010.

50 WANG, Daniel Wei Liang. Escassez de recursos, custo dos direitos e reserva do possivel na jurisprudência do STF. 2006. Disponível em: <http://escholarship.org/uc/item/26q0r0ns>Acesso em 20/09/2010.

51 LIMA, George Marmelstein. Análise econômica dos direitos fundamentais. Disponível em: <http:// direitosfundamentais.net/2007/12/14/analise-economica-dos-direitos-fundamentais/>. Acesso em: 16 out. 2010. 
segundo regras que pressupõe o direito igual ao bem e a impossibilidade do uso igual e simultâneo. Esse estado de escassez, muitas vezes, é resultado de um processo de escolha, de uma decisão. Quando não há recursos suficientes para prover todas as necessidades, a decisão do administrador de investir em determinada área implica escassez de recursos para outra que não foi contemplada. A título de exemplo, o gasto com festividades ou propagandas governamentais pode ser traduzido na ausência de dinheiro para a prestação de uma educação de qualidade..$^{52}$

Nessa quadra da exposição, merecem relevo as considerações que faz Ingo Wolfgang Sarlet, acerca do instituto da reserva do possível:

(...) há como sustentar que a assim designada reserva do possível, especialmente se compreendida em sentido mais amplo, apresenta pelo menos uma dimensão tríplice, que abrange a) a efetiva disponibilidade fática dos recursos para a efetivação dos direitos fundamentais; b) a disponibilidade jurídica dos recursos materiais e humanos, que guarda íntima conexão com a distribuição das receitas e competências tributárias, orçamentárias, legislativas e administrativas, entre outras, e que, além disso, reclama equacionamento, notadamente no caso do Brasil, no contexto do nosso sistema constitucional federativo; c) já na perspectiva (também) do eventual titular de um direito a prestações sociais, a reserva do possivel envolve o problema da proporcionalidade da prestação, em especial no tocante à sua exigibilidade e, nesta quadra, também da sua razoabilidade..$^{53}$ (grifo nosso)

Outrossim, o autor supracitado vai além em seus apontamentos, e alerta:

Todos os aspectos referidos guardam vínculo estreito entre si e com outros princípios constitucionais (por exemplo, os da igualdade e subsidiariedade), exigindo, além disso, um equacionamento sistemático e constitucionalmente adequado, para que, na perspectiva do princípio da máxima eficácia e efetividade dos direitos fundamentais, possam servir não como barreira instransponível, mas inclusive

52 STJ-REsp n. 1185474-SC. Min. Humberto Martins, j. 20/04/2010. Disponível em: <http://www.stj.jus.br/ $\mathrm{SCON} / j u r i s p r u d e n c i a / d o c . j s p ? l i v r e=r e s e r v a+d o+$ possivel\& $\& b=A C O R \& p=t r u e \& t=\& \mid=10 \& i=18>$. Acesso em: 18 ago. 2010.

3 SARLET, Ingo Wolfgang. Os direitos sociais como direitos fundamentais: contributo para um balanço aos vinte anos da Constituição Federal de 1988. Revista do Instituto de Hermenêutica Jurídica: 20 Anos de Constitucionalismo Democrático - E Agora? 2008. Disponivel em: <http://www.stf.jus.br/arquivo/cms/ processoAudienciaPublicaSaude/anexo/artigo_Ingo_DF_sociais_PETROPOLIS_final_01_09_08.pdf $>$. Acesso em: 07 out. 2010. 
como ferramental para a garantia também dos direitos sociais de cunho prestacional. ${ }^{54}$ (grifo nosso)

Em outra linha de raciocínio, note-se que as decisões judiciais acerca de tais direitos podem impactar as finanças do Estado, relacionando-se diretamente com a questão orçamentária, visto que resultam em priorização da aplicação de recursos públicos finitos; por isso alguns teóricos apontam a cláusula da reserva do possível como limite fático à exigibilidade desses direitos perante o Judiciário. Nesse sentido, Fernando Facury Scaff sustenta:

(...) quem determina as prioridades para a realização desses gastos públicos? No Brasil, como visto acima, deve ser o Poder Legislativo como aliás, em todos os países "ocidentais" -, através do sistema orçamentário, pois é nele que serão designadas as prioridades a serem implementadas em curto e médio prazo os objetivos de longo prazo estão previstos na Constituição. A isto se chama "discricionariedade do legislador" A função do Poder Executivo é a de realizar estes gastos, da forma e no limite estabelecidos pela lei. Claro que existe uma margem de "discricionariedade administrativa" mas esta é circunscrita pelas normas constitucionais e legais que regem as situações concretas sob responsabilidade da Administração. O papel do Poder Judiciário não é o de substituir o Poder Legislativo, não é o de transformar "discricionariedade legislativa" em "discricionariedade judicial", mas o de dirimir conflitos nos termos da lei. Proferir "sentenças aditivas" sob o impacto da pressão dos fatos, mesmo que dos fatos sociais mais tristes, como a possibilidade de perda de uma vida ou de falta de recursos para a compra de remédios, não é papel do Judiciário. Este não cria dinheiro; ele redistribui o dinheiro que possuía outras destinações estabelecidas pelo Legislativo e cumpridas pelo Executivo é o "Limite do Orçamento", de que falam os economistas, ou a "Reserva do Possível", dos juristas. ${ }^{55}$

\section{E alerta o jurista Fernando Facury Scaff:}

Esta evolução é seguramente um passo adiante no sistema de Justiça Constitucional no Brasil. É preciso ter cautela, contudo, para que dentre as decisões a serem proferidas, aquelas que se configurarem como sentenças aditivas ${ }^{56}$ não

Id. Ibid.

ss SCAFF, Fernando Facury. Sentenças aditivas, direitos sociais e reserva do possível. Revista Dialética de Direito Processual. Disponivel em: $<$ http://www.scaff.adv.br/cgibin/lista_doc.cgi?id usuario $=1000001 \& u$ $=1000000 \& \mathrm{~d}=2 \& \mathrm{dt}=20080508 \& \mathrm{c}=0 \&$ fl_backup $=0 \&$ data_backup $=($ null $)>$. Acesso em: 18 out. 2010 .

56 Segundo ele uma sentença aditiva é "aquela que implica aumento de custos para o Erário, obrigando-o ao reconhecimento de um direito social não previsto originalmente no orçamento do Poder Público 
venham a ser proferidas com efeitos financeiros imediatos contra os cofres públicos, sob pena de serem mantidas as mesmas dificuldades hoje existentes, apenas que sob outra roupagem..$^{57}$

E prossegue o jurista:

Ocorre que os recursos são escassos e as necessidades infinitas. Como o sistema financeiro é um sistema de vasos comunicantes, para se gastar de um lado precisa- se retirar dinheiro de outro. E aí será feito aquilo que no ditado popular se diz como "descobrir um santo para cobrir outro". Isto não quer dizer que o Judiciário não possa proferir "sentenças aditivas". Pode e deve fazê-lo nos limites da lei. ${ }^{58}$

Válido citar, neste diapasão, o entendimento do Ministro do Superior Tribunal de Justiça, Humberto Martins no Recurso Especial número 1185474/SC, em que reconheceu somente a real falta de recursos, efetivamente demonstrada pelo Poder Público como legitimadora do argumento da reserva do possível. Portanto a alegação não pode ser aventada como uma desculpa genérica para a omissão ou falha do Estado na seara da efetivação dos direitos fundamentais sociais. ${ }^{59}$

Nesse passo, convém salientar que em decisão de abril de 2010, a Segunda Turma do Superior Tribunal de Justiça, reconheceu a possibilidade de determinação judicial assegurar a efetivação dos direitos fundamentais, mesmo que impliquem custos ao orçamento do Executivo. ${ }^{60}$

demandado."

E exemplifica Scaff: (...) acontece quando a sentença determina a implementação de direitos sociais, sejam aqueles reconhecidos por leis e que não foram executados, sejam aqueles que decorrem de uma aplicação direta da Constituição - hipóteses mais comuns no Brasil atual.

57 SCAFF, Fernando Facury. Sentenças aditivas, direitos sociais e reserva do possível. Revista Dialética de Direito Processual. Disponível em: <http://www.scaff.adv.br/cgibin/lista_doc.cgi?id_usuario $=1000001 \& u$ $=1000000 \& \mathrm{~d}=2 \& \mathrm{dt}=20080508 \& \mathrm{c}=0 \&$ fl_backup $=0 \&$ data_backup $=($ null $)>$. Acesso em: 18 out. 2010 .

58 SCAFF, Fermando Facury. Sentenças aditivas, direitos sociais e reserva do possível. Revista Dialética de Direito Processual. Disponível em: $<\mathrm{http}: / /$ www.scaff.adv.br/cgibin/lista_doc.cgi?id_usuario $=1000001 \& \mathrm{u}$ $=1000000 \& \mathrm{~d}=2 \& \mathrm{dt}=20080508 \& \mathrm{c}=0 \&$ fl_backup $=0 \&$ data_backup $=($ null $)>$. Acesso em: 18 out. 2010 .

59 STJ, REsp 1185474-SC, Relator Humberto Martins, j. 20/04/2010. Disponivel em: <http://www.stj.jus.br/ SCON/jurisprudencia/toc.jsp>. Acesso em: 20 set. 2010.

so STJ, REsp 1185474-SC, Relator Humberto Martins, j. 20/04/2010. Disponível em: <http://www.stj.jus.br/ SCON/jurisprudencia/toc.jsp>. Acesso em: 20 set. 2010. 
No que tange à realização dos direitos fundamentais, impende assinalar que os direitos que mais são concedidos pela via judicial são o direito à saúde ${ }^{61}$ e à educação. ${ }^{62}$ Ainda assim, em que pese a Constituição Federal de 1988 determinar recursos mínimos para a implementação dos direitos retrocitados, os tribunais negam esses direitos com respaldo na alegação do argumento da reserva do possível.

Em arremate, cumpre frisar que, Sérgio Osborne Moreira Alves sustenta que a reserva do possível consiste na impossibilidade fática, desde que comprovada, de realizar determinada prestação, impedindo sua satisfação, todavia pode também ter um viés jurídico, pois a alocação de recursos é matéria tratada em lei orçamentária. ${ }^{63}$

Adverte, ademais, que o Judiciário deverá atuar ponderando os valores em conflito para conceder ou não o direito subjetivo à prestação, pois é imprescindível a discussão acerca das necessidades básicas frente às obrigações do Estado em satisfazê-las, tendo em vista a razoabilidade. Alerta para o inolvidável aspecto concernente ao caráter econômico dos direitos sociais prestacionais, para que se consiga implementá-los de forma sempre progressiva. ${ }^{64}$

61 TRF 4 ${ }^{a}$ Reg- AI n. 2008.04.00.030710-4/RS. Relator: Juiz Federal Roger Raupp Rios, j 30/09/2008: “O princípio de interpretação constitucional da concordância prática exige que se concretizem os direitos fundamentais emprestando-lhes a maior eficácia possível e evitando restrições desnecessárias a outros princípios constitucionais, bem como a ofensa a direitos fundamentais de outros indivíduos e grupos. No mesmo sentido: STF, Agravo Regimental no RE 271.286-8/RS, Relator: Min. Celso de Mello, j. 12/09/ 2000; TJ/RS AI 70019197383 Rel: Desa. Rejane Maria Dias de Castro Bins, j. 21/06/2007. Disponível em: $<$ http://www.prr4.mpf.gov.br/pesquisaPauloLeivas/index.php?pagina=jurisprudencia_nacional $>$. Acesso em: 21 set. 2010.

62 STF - Agravo Regimental no RE $n^{\sim}$ 436.996-6 São Paulo. Relator: Min. Celso de Mello, j. em 22.11. 2005. “(...) A educação infantil, por qualificar-se como direito fundamental de toda criança, não se expõe, em seu processo de concretização, a avaliações meramente discricionárias da Administração Pública, nem se subordina a razões de puro pragmatismo governamental. Embora resida, primariamente, nos Poderes Legislativo e Executivo, a prerrogativa de formular e executar políticas públicas, revela-se possivel, no entanto, ao Poder Judiciário, determinar, ainda que em bases excepcionais, especialmente nas hipóteses de políticas públicas definidas pela própria Constituição, sejam estas implementadas pelos órgãos estatais inadimplentes, cuja omissão - por importar em descumprimento dos encargos político-jurídicos que sobre eles incidem em caráter mandatório - mostra-se apta a comprometer a eficácia e a integridade de direitos sociais e culturais impregnados de estatura constitucional. A questão pertinente à "reserva do possível". Doutrina. No mesmo sentido: STJ, REsp n 575.280 - SP (2003/0143232-9). Relator: Min. José Delgado. Recorrente: MP do Estado de São Paulo. Recorrido: Município de Santo André. J. 02/09/2004. Disponível<http://www.prr4. mpf.gov.br/pesquisaPauloLeivas/index.php?pagina=jurisprudencia_nacional> Acesso em: 21 set. 2010.

63 ALVES, Sérgio Osborne Moreira. Os direitos fundamentais sociais, "reserva do possivel" $e$ proporcionalidade: desafios à concretização da constituição do estado democrático e social brasileiro. Disponivel em: <http://biblioteca.universia.net/html_bura/ficha/params/id/41432060.html . Acesso em: 09 set. 2010.

${ }^{64}$ ALVES, Sérgio Osborne Moreira. Os direitos fundamentais sociais, "reserva do possivel" $e$ proporcionalidade: desafios à concretização da constituição do estado democrático e social brasileiro. Disponível em: <http://biblioteca.universia.net/html_bura/ficha/params/id/41432060.html >. Acesso em: 09 set. 2010 . 
O desafio da efetivação dos direitos fundamentais sociais

Hodiernamente, é notável que a temática da efetividade dos direitos fundamentais sociais vem gerando desafiantes e imprescindíveis debates, quer pelo próprio Estado, quer pelos operadores do Direito Público, vislumbrando-se apenas tímida efetivação de tais direitos.

Ao se debruçar sobre a problemática da efetivação dos direitos fundamentais sociais, percebe-se que exsurgem várias barreiras, algumas ditas até intransponíveis. A título ilustrativo, vale citar o custo dos direitos que, embora diretamente ligado à escassez de recursos; o entrave da a ilegitimidade do Judiciário para intervir na formulação e implementação de políticas públicas e o instituto de origem tedesca: a reserva do possível.

Neste sentido, por oportuno, cabe mencionar que o enfoque desta pesquisa exclui da apreciação os direitos fundamentais sociais de defesa, visto que o cerne do trabalho gira em torno da efetivação dos direitos fundamentais sociais a prestações. ${ }^{65}$

Vale advertir, neste contexto que este trabalho abordará a questão da ilegitimidade democrática do Judiciário, envolvendo a separação dos poderes, porém o enfoque principal é o argumento da reserva do possível como limite fático, bem como os limites à sua aplicação, apontando inclusive a necessidade de novos parâmetros, critérios na técnica de ponderação quando da decisão judicial a conceder prestação, objeto de direito fundamental social.

Neste ponto, relevante é a lição de Érica Pessanha:

Não se pode esquecer também do caráter de complementaridade dos direitos fundamentais e da conexão dos direitos sociais com os individuais, civis e políticos. Sem as necessidades básicas supridas não há que se falar em plenitude de liberdade. Uma sociedade marcada por miséria, fome, alto índice de analfabetismo, pobreza e profundas desigualdades é, sem dúvida, uma sociedade que compromete a liberdade. Daí a importância de garantir-se a eficácia dos direitos sociais na maior medida possível. ${ }^{66}$ (grifo nosso)

Cabível também o ensinamento do Ministro do Superior Tribunal de Justiça, Humberto Martins:

É por esse motivo que, em um primeiro momento, a reserva do possível não pode ser oposta à efetivação dos Direitos Fundamentais, já que, quanto a estes, não cabe ao

\footnotetext{
65 CfWANG, Daniel Wei Liang. Escassez de recursos, custo dos direitos e reserva do possivel na jurisprudência do STF, 2006. Disponivel em: <http://escholarship.org/uc/item/26q0r0ns>. Acesso em: 20set . 2010.

66 PESSANHA, Érica. A eficácia dos direitos sociais prestacionais. Disponível em: <http://bdjur.stj.gov.br/ xmlui/handle/2011/24792>. Acesso em: 04 jul. 2010.
} 
administrador público preteri-los em suas escolhas. Nem mesmo a vontade da maioria pode tratar tais direitos como secundários. Isso, porque a democracia não se restringe na vontade da maioria. O princípio do majoritário é apenas um instrumento no processo democrático, mas este não se resume àquele. Democracia é, além da vontade da maioria, a realização dos direitos fundamentais. ${ }^{67}$ (grifo nosso)

Para Luciane Moessa de Souza: "As numerosas indagações colocadas por este tormentoso tema não encontrarão respostas enquanto não for devidamente exercido o controle de constitucionalidade em matéria financeira e orçamentária" Para a referida autora, mesmo os contornos do mínimo defendido, a ser exigido como direito subjetivo para que seja efetivado, termina onde se extrapola a reserva do possível. ${ }^{68}$

Já para o professor George Marmelstein diz: "Para que os direitos fundamentais sejam efetivados, é necessário que a Constituição faça parte da vida dos indivíduos" 69

Segundo leciona o professor Ingo Wolfgang Sarlet há os direitos fundamentais de defesa - de status negativo, e os direitos prestacionais - de status positivo, em sentido amplo e restrito. E alerta na direção de que aos direitos fundamentais sociais aplicam-se às normas em menor ou maior grau de eficácia, conforme suas palavras:

\begin{abstract}
(...) assumem habitualmente a feição, no que diz com a sua técnica de positivação e eficácia, de normas carentes de concretização legislativa, o que, de outra parte, não lhes retira pelo menos um certo grau de eficácia. Assim, verifica-se que a norma contida no art. $5^{\circ}, \S 1^{\circ}$, da CF, ainda que aplicável a todos os direitos fundamentais, não o poderá ser da mesma forma. ${ }^{70}$ (grifo nosso)
\end{abstract}

67 STJ, Recurso Especial n. 1185474-SC, Relator Humberto Martins, j. 20/04/2010. Disponível em: <http:// www.stj.jus.br/SCON/jurisprudencia/toc.jsp>. Acesso em: 20 set. 2010.

68 SOUZA, Luciane Moessa de. Reserva do possível x minimo existencial: o controle de constitucionalidade em matéria financeira e orçamentária como instrumento de realização dos direitos fundamentais. Disponível em: <http://www.conpedi.org.br/manaus/arquivos/anais/bh/luciane_moessa_de_souza2.pdf $>$. Acesso em: 05 jul. 2010.

69 Nesse sentido, no que tange ao enfrentamento da realidade social pelo Brasil, consoante observa o juiz federal George Marmelstein Lima:(..) paradoxalmente, é um dos países que apresentam os piores Índices de Desenvolvimento Humano, medido pelo PNUD - Programa das Nações Unidas para o Desenvolvimento, que incluem aspectos como mortalidade infantil, concentração de renda, analfabetismo, pobreza, desnutrição etc., ou seja, todas as carências básicas que os direitos sociais se propõem a combater. In: LIMA, George Marmelstein. Direitos fundamentais e frustração constitucional. Disponivel em: <http:// direitosfundamentais.net/2007/08/13/direitos-fundamentais-e-frustracao-constitucional/>. Acesso em: 13 ago. 2010.

70 SARLET, Ingo Wolfgang. Os direitos fundamentais na Constituição de 1988. Disponível em: <http://www. direitopublico.com.br/pdf_seguro/REVISTA-DLALOGO-JURIDICO-01-2001-INGO-SARLET.pdf>. Acesso em: 10 jul. 2010. 
Ainda, para o constitucionalista Ingo Wolfgang Sarlet:

(...) a melhor exegese da norma contida no art. $5^{\circ}, \S 1^{\circ}$, de nossa Constituição, é a que parte da premissa de que se cuida de norma de natureza principiológica, que, por esta razão, pode ser considerada como uma espécie de mandado de otimização (maximização), isto é, que estabelece para os órgãos estatais a tarefa de reconhecerem, à luz do caso concreto, a maior eficácia possível a todas as normas definidoras de direitos e garantias fundamentais (...) (grifo nosso) ${ }^{71}$

Note-se que a temática da cláusula da reserva do possível como óbice à concretização dos direitos sociais repousa no contexto do desafio da efetivação dos direitos fundamentais sociais que esbarra em vários outros empecilhos, verdadeiras muralhas erigidas em oposição à realização desses direitos.

Observe-se que a problemática ora pesquisada é complexa, abrangente, visto que se faz necessário referência a múltiplos aspectos a ela imbricados, sejam eles de caráter jurídico, econômico e político. Vinculada à questão, inclui-se a compreensão sobre outras teorias da esfera constitucional.

Com efeito, no que concerne à questão da reserva do possível, em audiência pública sobre o direito à saúde, um dos direitos fundamentais sociais, Ingo Sarlet leciona:

A reserva do possível constitui, em verdade (considerada toda a sua complexidade), espécie de limite jurídico e fático dos direitos fundamentais, mas também poderá atuar, em determinadas circunstâncias, como garantia dos direitos fundamentais, por exemplo, na hipótese de conflito de direitos, quando se cuidar da invocação - desde que observados os critérios da proporcionalidade e da garantia do mínimo existencial em relação a todos os direitos fundamentais - da indisponibilidade de recursos com o intuito de salvaguardar o núcleo essencial de outro direito fundamental. ${ }^{72}$

Nesta seara, outro ponto que merece relevo respeito á aplicabilidade imediata das normas de direitos fundamentais sociais. A aplicabilidade imediata, eficácia e

71 Cf SARLET, Ingo Wolfgang. Os direitos fundamentais na Constituição de 1988. Disponível em: <http:// www.direitopublico.com.br/pdf_seguro/REVISTA-DIALOGO-JURIDICO-01-2001-INGO-SARLET.pdf>. Acesso em: 04 jul. 2010.

72 SARLET, Ingo Wolfgang. Os direitos sociais como direitos fundamentais: contributo para um balanço aos vinte anos da Constituição Federal de 1988. O presente texto constitui versão revista, atualizada e parcialmente reformulada de trabalho redigido anteriormente sobre o tema, que, todavia, enfatizava, de um modo geral, o problema das resistências aos direitos sociais, e que, além de remetido para publicação em coletâneas (Editoras Forense e Saraiva) versando sobre os 20 anos da Constituição Federal de 1988, foi objeto de veiculação na Revista do Instituto de Hermenêutica Jurídica. 20 Anos de Constitucionalismo Democrático - E Agora? 2008, p. 163- 206. Disponível em: <http://www.stf.jus.br/arquivo/cms/ processoAudienciaPublicaSaude/anexo/artigo_Ingo_DF_sociais PETROPOLIS_final_01_09_08.pdf $>$. Acesso em: 07 jul. 2010. 
efetivação dos direitos fundamentais de cunho social exigem uma conduta estatal positiva, por isso são denominados direitos prestacionais.

Nesta perspectiva, interessa citar a lição do professor Ingo Wolfgang Sarlet:

Em que pese a localização topográfica do dispositivo, que poderia sugerir uma exegese restritiva, o fato é que, mesmo sob o ponto de vista da mera literalidade (o preceito referido é claro ao mencionar "as normas definidoras dos direitos e garantias fundamentais"), não há como sustentar uma redução do âmbito de aplicação da norma a qualquer das categorias específicas de direitos fundamentais consagradas na nossa Constituição (... $)^{73}$

Como há dissenso na doutrina sobre a natureza jurídica da reserva do financeiramente possível, adotar-se-á neste trabalho o entendimento que a considera como elemento externo ao direito, consoante leciona Ana Carolina Olsen Lopes; portanto, uma restrição e não elemento imanente dos direitos sociais. ${ }^{74}$

No tocante à diferença entre a natureza dos direitos de defesa e os direitos sociais, valem as observações de Érica Pessanha:

Quanto às diferenças em relação às liberdades, a doutrina analisa, em primeiro lugar, que, enquanto os direitos de defesa possuem natureza preponderantemente negativa, os direitos sociais pressupõem uma conduta positiva do Estado. A primeira característica inerente ao direito em questão é, portanto, o seu cunho prestacional. ${ }^{75}$

Em que pese a complexidade do problema, e até mesmo o risco decorrente de uma simplificação, vale ressaltar que dadas as limitações espaciais do presente trabalho, bem como intelectuais da pesquisadora, torna-se imperioso bem como intelectuais da pesquisadora, torna-se imperioso direcionar os rumos, ater-se ao enfoque escolhido. Desta forma, é mais sensato priorizar alguns dados de cunho mais genérico, restringindo

73 SARLET, Ingo Wolfgang. Os direitos sociais como direitos fundamentais: contributo para um balanço aos vinte anos da Constituição Federal de 1988. O presente texto constitui versão revista, atualizada e parcialmente reformulada de trabalho redigido anteriormente sobre o tema, que, todavia, enfatizava, de um modo geral, o problema das resistências aos direitos sociais, e que, além de remetido para publicação em coletâneas (Editoras Forense e Saraiva) versando sobre os 20 anos da Constituição Federal de 1988, foi objeto de veiculação na Revista do Instituto de Hermenêutica Jurídica. 20 Anos de Constitucionalismo Democrático - E Agora? 2008, p. 163- 206. Disponível em: <http://www.stf.jus.br/arquivo/cms/ processoAudienciaPublicaSaude/anexo/artigo_Ingo_DF_sociais_PETROPOLIS_final_01_09_08.pdf $>$. Acesso em: 07 out. 2010.

74 OLSEN, Ana Carolina Lopes. A eficácia dos direitos fundamentais sociais frente à reserva do possivel. Dissertação apresentada na UFPR, 2006. Disponível em: <http://dspace.c3sl.ufpr.br/dspace/ bitstream/1884/3084/1/Disserta $\%$ C3\%A7\%C3\%A3o\%20\%20Ana\%20Carolina $\% 20$ Lopes $\% 20$ Olsen.pdf $>$. Acesso em: 20 set. 2010.

75 PESSANHA, Érica. A eficácia dos direitos sociais prestacionais. Disponivel em: <http://bdjur.stj.gov.br/ xmlui/handle/2011/24792>. Acesso em: 04 jul. 2010. 
a abordagem dos inúmeros aspectos passíveis de serem expostos neste contexto. No entanto, tem-se o único escopo contribuir um pouco para a discussão acerca da efetivação dos direitos sociais.

De fato, imprescindível frisar que um desses aspectos já bastante enfrentado pela doutrina é atinente à aplicabilidade imediata das normas que definem os direitos fundamentais sociais. E nesta trilha, convém destacar, por oportuno o que adverte o professor Ingo Sarlet:

(...) a nossa Constituição, no âmbito da fundamentalidade formal dos direitos fundamentais, previu, expressamente, em seu art. $5^{\circ}$, parágrafo $1^{\circ}$, que "as normas definidoras dos direitos e garantias fundamentais têm aplicação imediata" Tal formulação, à evidência, traduz uma decisão inequívoca do nosso Constituinte no sentido de outorgar às normas de direitos fundamentais uma normatividade reforçada e, de modo especial, revela que as normas de direitos e garantias fundamentais não mais se encontram na dependência de uma concretização pelo legislador infraconstitucional, para que possam vir a gerar a plenitude de seus efeitos, de tal sorte que permanece atual a expressiva e multicitada frase de Herbert Krüger, no sentido de que hoje não há mais falar em direitos fundamentais na medida da lei, mas sim, em leis na medida dos direitos fundamentais.(grifo nosso) ${ }^{76}$

Mister se faz assinalar que a efetividade dos direitos sociais pode ser entendida como a concretização dos efeitos jurídicos no mundo dos fatos, isto é, a materialização do direito. Ingo Wolfgang Sarlet diz que se deve extrair das normas definidoras de direitos fundamentais, os efeitos jurídicos que lhe são peculiares, mesmo sem uma interposição do legislador, devendo ser efetivados, ou senão acabariam ao dispor dos órgãos estatais. ${ }^{77}$

Outrossim, salienta o supracitado professor que os direitos fundamentais sociais, contrariamente ao que propugna ainda boa parte da doutrina, não podem mais ser considerados meros enunciados sem força normativa, limitados a proclamações de boas intenções e veiculando projetos que poderão, ou não, ser objeto de concretização, dependendo única e exclusivamente da boa vontade do poder público, em especial, do legislador. ${ }^{78}$

O constitucionalista Ingo Wolfgang Sarlet diz que:

76 SARLET, Ingo Wolfgang. Algumas considerações em torno do conteúdo, eficácia e efetividade do direito à saúde na Constituição de 1988. Revista Diálogo Jurídico, Salvador, n. 10, jan. 2002. Disponível em: <http:// www.buscalegis.ufsc.br/revistas/index.php/buscalegis/article/viewFile/31953/31199>. Acesso em: 20 ago. 2010.

$7 \%$ Id. Ibid.

78 Id. Ibid. 
Consequentemente, diante do caso concreto, o Magistrado se depara com o dilema: Direitos Fundamentais Sociais X "Reserva do possível" Novamente, o primeiro obstáculo a ser enfrentado, é o da violação ao Princípio da Separação de Poderes, sob a alegação de que os Juizes estariam adentrando na alçada Executiva e Legislativa, sob o argumento de que em matéria de recursos públicos, apenas o legislador democraticamente legitimado possui competência para decidir sobre a afetação destes recursos. ${ }^{79}$ (sic)

O jurista Clèmerson Merlin Clève entende que no que diz respeito aos questionamentos acerca da legitimidade do Poder Judiciário, importa verificar os limites impostos no que concerne à atividade do Judiciário, também, pelo princípio da separação dos poderes. ${ }^{80}$

Outrossim, necessário se faz superar o problema da legitimidade democrática do Poder Judiciário. O professor constitucionalista alerta para o fato de que no cenário de um Estado Democrático de Direito, com poderes divididos, há que se ter em mente os limites do Judiciário, enquanto instância garantidora dos direitos fundamentais. ${ }^{81}$

O postulado que impõe a maximização da eficácia e efetividade de todos os direitos fundamentais não implica em desconsiderar as peculiaridades de determinadas normas de direitos fundamentais, admitindo, dadas as circunstâncias, alguma relativização, visto a natureza aberta e indeterminada das normas que os definem na Constituição Federal. É importante notar que, quando o Poder Público se nega a cumprir qualquer obrigação fundada nos direitos fundamentais sociais configura-se o não reconhecimento dos direitos sociais como verdadeiros direitos. ${ }^{82}$

Gize-se, por outro lado que, na esteira da lição do professor Clèmerson Merlin Clève, não se deve olvidar que os direitos fundamentais sociais "são direitos de satisfação progressiva, cuja realização encontra-se estritamente ligada ao PIB (Produto Interno Bruto) e, portanto, à riqueza do país" 83

\footnotetext{
79 SARLET, Ingo Wolfgang. Algumas considerações em torno do conteúdo, eficácia e efetividade do direito à saúde na Constituição de 1988. Revista Diálogo Jurídico, Salvador, n. 10, jan. 2002. Disponível em: <http:// www.buscalegis.ufsc.br/revistas/index.php/buscalegis/article/viewFile/31953/31199>. Acesso em: 20 ago. 2010.

80 CLĖVE, Clèmerson Merlin. A eficácia dos direitos sociais. Revista de Direito Constitucional e Internacional, São Paulo, ano 14, n. 54, jan./mar. 2006.

81 Id. Ibid

82 STF, $A D P F$ n. 45 MC/DF- Medida Cautelar em ADPF, j. 29/04/2004. Disponível em: <http://www.stf.jus. br/portal/jurisprudencia/listarJurisprudencia.asp?s1=45.NUME.\&base=baseMonocraticas $>$. Acesso em: 09 jul. 2010.

83 CLÈVE, Clèmerson Merlin. A eficácia dos direitos fundamentais sociais. cit., p. 34.
} 
Ao fazer referência à atuação do juiz na efetivação dos direitos sociais, observa Carin Zeni que, o Poder Judiciário não deve temer a função de assegurar o cumprimento da Constituição. ${ }^{84}$

No entanto, alerta para a necessidade de observar conceitos como da reserva de consistência e da reserva do possível, os quais devem seguir juntos para atingir uma solução de modo a não ferir os ideais democráticos da nossa Constituição. Destarte, devese atentar para os limites da atuação judicial nesta gama de direitos, pois a judicialização da política pode implicar na inaceitável politização do Poder Judiciário. ${ }^{85}$

Entretanto, imprescindível lembrar que o Brasil é um Estado Democrático e Social de Direito, pelos valores, princípios e objetivos fundamentais ${ }^{86}$ que elegeu para nortear sua Constituição. É bom lembrar que, por ser Estado de Direito, em que há o império da lei, o próprio Estado deve submeter-se, obedecer também às normas $\mathrm{e}$ princípios de sua Lei Máxima.

O Brasil instituiu um Estado Democrático, cuja finalidade é assegurar o exercício dos direitos sociais e individuais, a liberdade, a segurança, o bem-estar, o desenvolvimento, a igualdade e a justiça social como valores supremos da sociedade.

Dessa forma, inolvidável o fato de que o Estado não pode se negar a cumprir os mandamentos constitucionais, no mínimo deve dar máxima efetividade às normas de direitos fundamentais sociais. ${ }^{87}$

Os professores Ingo Wolfgang Sarlet e Mariana Filchtiner Figueiredo salientam que:

(...) as perplexidades e contradições que enfrentamos
devem-se às próprias carências do sistema de proteção dos
direitos socais como um todo, agravadas pelas dificuldades
de um país marcado por tamanhas desigualdades sociais e
regionais como o Brasil. Se o caminho do desenvolvimento
humano passa pela construção de instrumentos de tutela e
de implementação de todos os direitos fundamentais, com
especial ênfase sobre os direitos sociais, o igual respeito
à dignidade de todo o brasileiro e a certeza de que terá
condições adequadas de se desenvolver como pessoa e

84 ZENI, Carin. O poder judiciário como legislador positivo na efetivação dos direitos fundamentais sociais. Revista Discurso Juridico, v. 3, n. 2, jul./dez. 2007, p. 129-148. Disponível em: <http://revista. grupointegrado.br/revista/index.php/discursojuridico/article/view/217/103>. Acesso em: 20 set. 2010.

85 Id. Ibid.

${ }^{86}$ CF 88, Art $1^{\circ}$, inciso II - a cidadania; inciso III - a dignidade da pessoa humana; IV - promover o bem de todos; Título VIII, Art. 193. A ordem social tem como base o primado do trabalho, e como objetivos o bemestar e a justiça social.

87 SARLET, Ingo Wolfgang; FIGUEIREDO, Mariana Filchtiner. Algumas considerações sobre o direito fundamental à proteção e promoção da saúde aos 20 anos da Constituição Federal de 1988. Disponivel em: <http://www.stf. jus.br/arquivo/cms/processoAudienciaPublicaSaude/anexo/O_direito_a_saude_nos_20_anos_da_CF_coletanea TAnia_10_04_09.pdf>. Acesso em: 20 ago. 2010. 
cidadão pressupõem essa reflexão, no âmbito do direito fundamental à saúde e, mais amplamente, dos demais direitos sociais. ${ }^{88}$ (grifo nosso)

Neste momento, impende realçar que Ana Carolina Lopes Olsen entende que a da reserva do possível possui três dimensões a serem consideradas: a perspectiva fática e a jurídica, além da dimensão política. Em primeiro lugar, o aspecto fático deste instituto diz respeito á disponibilidade de recursos (financeiros). Por outro lado, encontrase o componente jurídico, que consiste na dependência de previsão na lei orçamentária do Estado (LOA - Lei Orçamentária Anual), que prevê receitas, bem como autoriza as despesas, na questão em foco, dispêndio com determinadas políticas públicas que contemplem direitos fundamentais sociais. ${ }^{89}$

Noutro vértice, no que tange à esfera política, inquestionável a necessidade de considerar a dependência da correta alocação dos escassos recursos públicos, que é feita a partir de opções, escolhas políticas. Importa que o Estado atente para as suas prioridades que, por seu turno, precisam se pautar pelos objetivos insculpidos em sua Lei Maior. ${ }^{90}$

Nesse sentido, o posicionamento do Ministro Celso de Mello, na Arguição de Descumprimento de Preceito Fundamental - ADPF n. 45/DF, faz considerações sobre os limites do Judiciário no que concerne à sua intervenção:

É que a realização dos direitos econômicos, sociais e culturais - além de caracterizar-se pela gradualidade de seu processo de concretização - depende, em grande medida, de um inescapável vínculo financeiro subordinado às possibilidades orçamentárias do Estado, de tal modo que, comprovada, objetivamente, a incapacidade econômico-financeira da pessoa estatal, desta não se poderá razoavelmente exigir, considerada a limitação material referida, a imediata efetivação do comando fundado no texto da Carta Política. (grifo nosso). ${ }^{91}$

88 SARLET, Ingo Wolfgang; FIGUEIREDO, Mariana Filchtiner. Algumas considerações sobre o direito fundamental à proteção e promoção da saúde aos 20 anos da Constituição Federal de 1988. Disponivel em: <http://www.stf. jus.br/arquivo/cms/processoAudienciaPublicaSaude/anexo/O_direito_a_saude_nos_20_anos_da_CF_coletanea_ TAnia_10_04_09.pdf>. Acesso em: 20 ago. 2010.

89 OLSEN, Ana Carolina Lopes. A eficácia dos direitos fundamentais sociais frente à reserva do possivel. Dissertação apresentada na UFPR, 2006. Disponível em: <http://dspace.c3sl.ufpr.br/dspace/ bitstream/1884/3084/1/Disserta\%C3\%A7\%C3\%A30\%20\%20Ana\%20Carolina\%20Lopes\%20Olsen.pdf $>$. Acesso em: 20 set. 2010.

90 Id. Ibid.

$91 \mathrm{STF}, A D P F$ n. 45 MC/DF- MC em ADPF, j. 29/04/2004. Disponivel em: <http://www.stf.jus.br/portal/ jurisprudência/listarJurisprudencia.asp?sl=45.NUME.\&base=baseMonocraticas $>$. Acesso em: 09 jul. 2010. 
Cumpre apontar que, na esteira dos ensinamentos de Ana Carolina Lopes Olsen, no debate sobre a problemática atual da efetivação dos direitos fundamentais sociais reside uma tensão entre o princípio constitucionalista (em que o Estado deve ter como função precípua a proteção e promoção dos direitos fundamentais) e o princípio democrático. ${ }^{92}$

É notável a dificuldade em delimitar o objeto dos direitos sociais a prestações, em virtude de apresentarem normas de natureza aberta, imprecisa, indeterminada.

Conforme leciona Ingo Wolfgang Sarlet, os direitos sociais:

(...) estão condicionados, no que diz com a sua realização, pela disponibilidade de recursos e pela capacidade de deles dispor (princípio da reserva do possivel), bem como pelo princípio democrático da reserva parlamentar em matéria orçamentária, o que também afeta o princípio da separação de poderes, entendemos que a proposta de solução deverá passar necessariamente pela ponderação dos princípios incidentes na espécie $(\ldots)^{93}$

De outra banda, quanto à efetividade dos direitos sociais, Ewerton Teixeira Bueno assevera:

Em verdade, ainda que não exista lei que viabilize o gozo imediato desses direitos, é dever do Estado através do Executivo ou Judiciário procurar, dentro dos seus limites, sanar as omissões do Legislativo, tendo como premissa base o princípio constitucional da máxima efetividade, principio este, que orienta os aplicadores da Lei Maior para que interpretem as suas normas em ordem a otimizar-lhes a eficácia, sem alterar o seu conteúdo. ${ }^{94}$ (grifo nosso)

Convém sublinhar que os direitos fundamentais sociais têm uma dimensão econômica relevante e por isso esbarra, encontra na trilha rumo à sua concretização como óbice o argumento da reserva do possível, cujo maior fundamento é a escassez de recursos públicos.

Contudo, vale lembrar a advertência feita por José Eduardo Faria de que:

92 OLSEN, Ana Carolina Lopes. A eficácia dos direitos fundamentais sociais frente à reserva do possivel. Dissertação apresentada na UFPR, 2006. Disponivel em: <http://dspace.c3sl.ufpr.br/dspace/ bitstream $/ 1884 / 3084 / 1 /$ Disserta $\%$ C3\%A7\%C3\%A30\%20\%20Ana\%20Carolina\%20Lopes\%20Olsen.pdf $>$. Acesso em: 20 set. 2010.

93 SARLET, Ingo Wolfgang. Algumas considerações em torno do conterido, eficácia e efetividade do direito à saúde na constituição de 1988. Disponivel em: <http://www.buscalegis.ufsc.br/revistas/index.php/buscalegis/article/ viewFile/31953/31199>. Acesso em: 06 jul. 2010.

94 BUENO, Ewerton Teixeira. Efetividade dos direitos sociais. Revista internacional direito e cidadania. Disponivel em: <http://www.iedc.org.br/REID/arquivos/00000093-reid4-04-ewerton.pdf >. Acesso em: 18 jul. 2010 . 
(...) o entendimento que ainda hoje prevalece é que "sem a devida regulamentação" por meio de uma lei complementar, esses direitos e essas prerrogativas têm vigência formal, mas são materialmente ineficazes" uma vez que não são capazes de gerar vínculos de direitos subjetivos. Nessa esteira, boa parte da jurisprudência ainda considera que, diante da omissão do Legislativo, não é dado ao o juiz, arvorando-se em legislador, criar o direito novo para caso concreto, sob pena de violar o princípio da independência dos poderes. $\mathrm{O}$ mesmo autor conclui que "a magistratura brasileira tem desprezado o desafio de preencher o fosso entre o sistema jurídico vigente e as condições reais da sociedade, em nome da "segurança jurídica" e de uma visão por vezes ingênua do equilíbrio entre os poderes autônomos. ${ }^{95}$

De outra feita, frente a tal alegação urge que o Estado programe os seus orçamentos rumo à efetivação progressiva dos direitos fundamentais sociais, uma vez que deve caminhar no sentido de cumprir seus objetivos plasmados na Constituição Federal de $1988 .{ }^{96}$

No âmbito da problemática em estudo, frise-se que a reserva do possível é uma restrição às normas de direitos fundamentais sociais, uma restrição ao direito, podendo ser relativizada. Deve ser suplantada sempre que estiver em jogo, ou melhor, em risco o princípio do mínimo existencial, condições mínimas à vida com dignidade. Portanto não é um obstáculo intransponível, consoante leciona Ana Carolina Lopes Olsen. ${ }^{97}$

Sérgio Osborne Moreira Alves diz:

A teoria da Reserva do Possível é condicionada pelas disponibilidades orçamentárias, porém os legisladores não possuem ampla Liberdade de Conformação, pois estão vinculados ao Princípio da Supremacia Constitucional, devendo implementar os objetivos estabelecidos na Constituição de 1988 , que se encontram no art. $3^{\circ}$., dentre outras normas-objetivo. ${ }^{98}$

95 FARIA, José Eduardo (Org.). O Judiciário e os direitos humanos e sociais. São Paulo: Malheiros, 2002. p. 99.

96 OLSEN, Ana Carolina Lopes. A eficácia dos direitos fundamentais sociais frente à reserva do possivel. Dissertação apresentada na UFPR, 2006. Disponivel em: <http://dspace.c3sl.ufpr.br/dspace/ bitstream $/ 1884 / 3084 / 1 /$ Disserta\%C3\%A7\%C3\%A3o\%20\%20Ana\%20Carolina\%20Lopes\%20Olsen.pdf $>$. Acesso em: 20 set. 2010.

97 OLSEN, Ana Carolina Lopes. A eficácia dos direitos fundamentais sociais frente à reserva do possivel. Dissertação apresentada na UFPR, 2006. Disponivel em: <http://dspace.c3sl.ufpr.br/dspace/ bitstream/1884/3084/1/Disserta\%C3\%A7\%C3\%A30\%20\%20Ana\%20Carolina\%20Lopes\%20OIsen.pdf>. Acesso em: 20 set. 2010.

98 ALVES, Sérgio Osborne Moreira. Os direitos fundamentais sociais, "reserva do possivel" $e$ proporcionalidade: desafios à concretização da constituição do estado democrático e social brasileiro. Disponível em: <http://biblioteca.universia.net/html_bura/ficha/params/id/41432060.html $>$. Acesso em: 08 ago. 2010. 
O procurador regional da República Paulo Gilberto Cogo Leivas observa

que:

O direito constitucional contemporâneo desenvolveu uma metodologia de decisão, chamada proporcionalidade em sentido amplo, que pode ser utilizada no processo de judicialização dos direitos sociais e compreende três etapas: adequação, necessidade e proporcionalidade em sentido estrito. Isso ocorre da seguinte forma: parte-se de um direito social prima facie que garante, de modo o mais amplo possível, prestações sociais. ${ }^{99}$ (grifo nosso)

No que tange à efetividade dos direitos sociais, Ewerton Teixeira Bueno

observa:

Destarte, no Estado Democrático de Direito, cumpre
ao Estado-Juiz impor obrigações de fazer ao Estado
Administração quando este omitir-se em cumprir os seus
deveres constitucionais. Em casos análogos, o juiz não estará
indo além de suas funções jurisdicionais, mas tão somente
levando a efeito o seu mister constitucional, aplicando o
direito ao caso concreto. ${ }^{100}$

Ao analisar os direitos fundamentais sociais, considerando-se de conteúdo amplo, com suporte fático amplo, teriam seu objeto determinável somente pelo magistrado, ao realizar o processo de ponderação, sopesando interesses, bens e valores jurídicos, em face das particularidades de um específico caso concreto. Rejeitando-se então a defesa de que seriam direitos, posições jurídicas definitivas. ${ }^{101}$

É cediço que os direitos fundamentais sociais têm um custo, pois reclamam prestações positivas do Estado. Contudo impende realçar já está assente na doutrina que todo direito tem um custo, sejam os direitos de liberdade ou de defesa, sejam os direitos sociais. ${ }^{102}$

Desta feita, necessário se faz reportar à análise feita pelo professor Sérgio Ferraz na direção de esclarecer o instituto da reserva do possível que, segundo o autor:

99 LEIVAS, Paulo Gilberto Cogo. Princípios de direito e de justiça na distribuição de recursos escassos. Revista Bioética, v. 14, n. 1, 2007. Disponível em: <http://www.portalmedico.org.br/revista/biol4v1/artigos/ artigo01.htm>. Acesso em: 08 ago. 2010

100 BUENO, Ewerton Teixeira. Efetividade dos direitos sociais. Revista internacional direito e cidadania. Disponível em: <http://www.iedc.org.br/REID/arquivos/00000093-reid4-04-ewerton.pdf>. Acesso em: 18 jul. 2010 .

101 SILVA, Vurgílio Afonso da. O conteúdo essencial dos direitos fundamentais e a eficácia das normas constitucionais. Revista de Direito do Estado, n. 4, p. 23-51, 2006. Disponível em: <http:// teoriaedireitopublico.com.br/pdf/2006-RDE4-Conteudo_essencial.pdf>. Acesso em: 08 ago. 2010.

102 WANG, Daniel Wei Liang. Escassez de recursos, custo dos direitos e reserva do possivel na jurisprudência do Supremo Tribunal Federal. 2006. Disponivel em: <http://escholarship.org/uc/item/26q0r0ns>. Acesso em: 20 set. 2010 . 
(...) deve ser buscado em duas vertentes. Em primeiro lugar a reserva do possível não pode ser, na verdade, um rótulo que obste, em caráter peremptório categórico, a atuação de controle jurisdicional das políticas públicas. Não é possível que se diga isso. Não nos esqueçamos de que, no sistema constitucional brasileiro, o orçamento é autorizativo e, afora as vinculações constitucionais e que são essas sim positivas, ele apenas é uma previsão de receitas e despesas. Consequentemente, o núcleo duro que existe de afetação constitucional realmente existe e não é pequeno e isso é bom que se diga, mas há todo um outro contingente, e o que existe são meras previsões, na verdade, de realização de recursos e de afetação de despesas. É neste campo que a judicialização ou o controle jurisdicional das políticas públicas tem uma província excelsa de realização. ${ }^{103}$

Ao se tratar da cláusula da reserva do possível, saliente-se que no que tange à sua dimensão fática, esta se encontra intimamente ligada ao problema da escassez de recursos financeiros. Ora, se os bens são escassos é exatamente por isso que devem ser distribuídos de forma justa, igual, para que se atinja a igualdade material. ${ }^{104}$

Já o professor Sérgio Ferraz, no que diz respeito à judicialização das políticas públicas, sustenta que:

Determinar que certos recursos sejam aplicados para dar
resposta a situações de risco de vida, de sobrevivência do
administrado, do cidadão e determinar, portanto, ao poder
público que invista dinheiro naquele campo e naquele desafio
que lhe é posto, na verdade, não obstante a existência dessa
central, como muito bem lembrou o Marrey, não existe, mas
devia existir realmente a busca para saber realmente aonde o
dinheiro vai, onde já foi e aonde ele ainda vai. ${ }^{105}$

Importa notar que, via de regra, tendo em vista não haver recursos financeiros suficientes para prover as inúmeras necessidades humanas sociais, o problema da escassez de recursos, que é fruto de escolhas, de decisões, opções políticas deve ser enfrentado pelo administrador com seriedade, que deve estar consciente de que investindo em determinada área implicará escassez de recursos para outra que não foi contemplada. ${ }^{106}$

\footnotetext{
103 FERRAZ, Sérgio. In: Degravação do Congresso Direito, política e economia intersecções e fronteiras no reconhecimento e implementação de direitos. 2010. Disponível em: <http://www3.esmpu.gov.br/materialdidatico/degravac327a303o_congresso_poli301tica.pdfs. Acesso em: 14 jun. 2010.

104 CLĖVE, Clèmerson Merlin. A eficácia dos direitos sociais. Revista de Direito Constitucional e Internacional, São Paulo, ano 14, n. 54, jan./mar. 2006.

105 FERRAZ, Sérgio. Degravação do Congresso... cit.

106 OLSEN, Ana Carolina Lopes. A eficácia dos direitos fundamentais sociais frente à reserva do possivel. cit.
} 
À guisa de ilustração desta questão acima apontada, o gasto com festividades ou propagandas institucionais podem ser traduzidos na ausência de dinheiro para a prestação de uma educação adequada, um serviço de saúde com qualidade. ${ }^{107}$

\subsection{A (i)legitimidade democrática do judiciário na efetivação dos direitos fundamentais sociais}

Em que pese os argumentos da reserva do possível, da separação de poderes, da discricionariedade - da conveniência e oportunidade - da atividade administrativa, com a alegação de que somente os poderes políticos podem tomar decisões que envolvam a esfera orçamentária e atuar na esfera das políticas públicas, ainda assim cabe apontar a relevância do papel do Judiciário como efetivador dos direitos fundamentais sociais prestacionais. Afastar esta opção não parece ser a melhor postura em qualquer cenário que envolva direitos fundamentais, mormente os de índole prestacional. ${ }^{108}$

Marcelo Rebello Pinheiro, no que se refere ao argumento da falta de legitimidade democrática dos juízes para intervir na questão das políticas públicas, entende ser evidente que os poderes Executivo e Legislativo são os mais legitimados para decisões, escolhas orçamentárias, direcionamento dos gastos públicos, pois foram escolhidos democraticamente pelo voto popular. Entretanto, ao Poder Judiciário também cabe colaborar para que se atinjam os objetivos plasmados na Constituição Federal, mormente a justiça social.

Ainda com supedâneo no autor acima citado, nota-se que há argumentação de que são os poderes políticos mais habilitados, por conhecerem a realidade orçamentária, bem como as demandas sociais, mas muitas vezes os poderes políticos fazem escolhas trágicas, negligenciando os direitos fundamentais sociais, aplicando os escassos recursos públicos em desrespeito aos ditames constitucionais.

De fato, partindo-se da premissa de que os juízes não são eleitos pelo povo, além do fato de não possuírem conhecimento técnico para questões orçamentárias, seria ilegítima a princípio, a intervenção do Poder Judiciário na seara das políticas sociais, ao efetivar determinados direitos fundamentais sociais, violaria portanto o princípio da separação dos poderes, bem como o princípio da discricionariedade administrativa. ${ }^{109}$

107 PINHEIRO, Marcelo Rebello. A eficácia e a efetividade dos direitos sociais de caráter prestacional: em busca da superação de obstáculos. Dissertação apresentada na UnB, 2008. Disponivel em: <http:// repositorio.bce.unb.br/bitstream/10482/5143/1/2008_MarceloRebelloPinheiro.pdf>. Acesso em: 08 set. 2010.

108 SILVA, Virgílio Afonso da. O conteúdo essencial dos direitos fundamentais e a eficácia das normas constitucionais. Revista de Direito do Estado, n. 4, p. 23-51, 2006. Disponivel em: <http:// teoriaedireitopublico.com.br/pdf/2006-RDE4-Conteudo essencial.pdf>. Acesso em: 08 ago. 2010.

109 PINHEIRO, Marcelo Rebello. A eficácia e a efetividade dos direitos sociais de caráter prestacional: em busca da superação de obstáculos. Dissertação apresentada na UnB, 2008. Disponível em: <http://repositorio. 
Contudo, deve-se interpretar as normas pela ótica constitucional, que considera os direitos fundamentais o cerne da Lei Maior do país.

No tocante à legitimidade do Judiciário para intervir na seara das políticas públicas, consoante leciona o professor Rubens Beçak nos oferece a seguinte observação:

Não se deve deixar de mencionar que os próprios poderes incumbidos do processo político têm contribuído para esta situação, na medida em que se observa que muitas vezes são estes próprios poderes, notadamente o legislativo, que recorrem ao STF, buscando respostas políticas deste órgão. ${ }^{110}$

Entretanto, mister se faz ressaltar que o problema relacionado à legitimidade constitucional do controle e da intervenção do Poder Judiciário em tema de implementação de políticas públicas, segundo entendimentos explanados em julgados do Supremo Tribunal Federal é que, quando configurada hipótese de abusividade governamental, omissão ou falha cabe ao Judiciário intervir no sentido de efetivar os direitos fundamentais. ${ }^{11}$

O professor das Arcadas, José Reinaldo de Lima Lopes diz:

Ao Judiciário incumbe, pois, para desempenhar hoje seu papel histórico num Estado democrático, dar-se conta do modelo de Estado, de sociedade e de conflitos em que está imerso, escapar da ilusão liberal mais simples de que, sua missão se reduz á proteção da propriedade privada e que as reformas sociais de que necessitamos (não) virão por si, sem a sua participação. ${ }^{112}$

De acordo com Marcelo Rebello Pinheiro, é válido ter em mira que a intervenção do Judiciário é cabível quando os poderes políticos são omissos e quando falham. Contudo, salienta que esta falta, falha, omissão deve ser efetivamente comprovada, demonstrada de forma consistente. ${ }^{113}$

De outra banda, no caso de necessidade de atuação do Judiciário nesta seara, este deve intervir, desde que aplique o princípio da proporcionalidade, em que analisará a adequação, necessidade e proporcionalidade stricto sensu. ${ }^{114}$

Portanto, para o autor diante da negligência do Poder Público cabe ao Judiciário intervir, ainda que seja uma intervenção mínima. Alerta ser inadmissível que o

bce.unb.br/bitstream/10482/5143/1/2008 MarceloRebelloPinheiro.pdf>. Acesso em: 08 set. 2010.

110 BEÇAK, Rubens. A separação dos poderes, o tribunal constitucional e a "judicialização da política". Revista da Faculdade de Direito da Universidade de São Paulo, São Paulo, v.103, p. 325-336, jan./dez. 2008.

III STF, Agr. Reg. no RE n. 367432/PR, cujo Relator foi o Min. Eros Grau, j. 20/04/2010. Disponível em: $<\mathrm{http}: / /$ www.jusbrasil.com.br/filedown/dev0/files/JUS2/STF/IT/REAGR_271286_RS\%20_12.09.2000. pdf $>$. Acesso em: 20 set. 2010.

112 LOPES, José Reinaldo de Lima. Direito subjetivo e direitos sociais: o dilema do Judiciário no Estado Social de Direito. In: FARIA, José Eduardo (Org.). Direitos humanos, direitos sociais e justiça. São Paulo: Malheiros, 2002. p. 127.

113 PINHEIRO, Marcelo Rebello. A eficácia e a efetividade dos direitos sociais de caráter prestacionais... cit. 114 Id. Ibid. 
magistrado vá além em suas decisões, ao determinar uma obrigação de fazer ao Estado, de prestar um direito social, como também determinar o redirecionamento de verbas públicas. Pinheiro entende ainda que o redirecionamento da verba, devido à discricionariedade da atividade administrativa deve mesmo ficar a cargo do Poder Público. ${ }^{115}$

Conforme leciona o professor José Eduardo Faria:

A concreção dos direitos humanos e sociais previstos pelos textos constitucionais muitas vezes é negada pelos diferente braços - diretos e indiretos - do poder público. Trata-se de uma negação sutil, que costuma se dar por via de uma "interpretação dogmática" do direito, enfatizando-se, por exemplo, a inexistência de leis complementares que regulamentem os direitos e as prerrogativas assegurados pela Constituição. ${ }^{116}$ (grifo nosso)

No contexto de implementação dos direitos fundamentais sociais, além da garantia do mínimo existencial que deve ser preservado de forma integral, devido ao seu caráter de intangibilidade, não se deve olvidar que a liberdade de conformação do legislador não é absoluta.

Note-se que, no âmbito do Poder Executivo federal, há inúmeras políticas públicas que visam atender direitos sociais, contudo há nítida falta de efetividade, vide aumento gradativo das desigualdades sociais no Brasil. De outra banda, pode-se constatar que também há nas outras esferas do Executivo negligenciamento, certo descaso com as necessidades sociais. ${ }^{117}$

3.1.1. O princípio da separação dos poderes

Ressalte-se que o postulado do princípio da separação dos poderes surge como um pseudo-óbice à efetivação dos direitos fundamentais sociais, pois o artigo $2^{\circ}$ da Lei Fundamental pátria prescreve a independência e harmonia entre os poderes. No entanto, essa norma não é absoluta, pois há que se observar que, no âmbito do Estado Democrático de Direito, também há o princípio dos freios e contrapesos, além de outros atinentes a essa

115 Id. Ibid.

116 FARIA, José Eduardo(Org.). O Judiciário e os direitos humanos e sociais. São Paulo: Malheiros, 2002. p. 98.

117 Cf STJ, Recurso Especial n. 1/85474/SC, de relatoria do Min. Humberto Martins, no qual o Ministro observa que: "a determinação judicial do dever pelo Estado não caracteriza ingerência do Judiciário na esfera administrativa. A atividade desse dever é vinculada ao administrador, uma vez que se trata de direitos consagrados. Cabe ao Judiciário, por fim, torná-lo realidade, mesmo que para isso resulte obrigação de fazer, podendo repercutir na esfera orçamentária. Disponível em: <http://www.stj.jus.br/SCON/pesquisar. jsp?newsession=yes\&tipo_visualizacao=RESUMO\&b=ACOR\&livre=Resp 1185474>. Acesso em: 07 jul. 2010. 
questão, como o princípio da máxima efetividade das normas constitucionais e do próprio acesso amplo à justiça.

Um poder pode interferir no outro, desde que o outro poder esteja em desrespeito às normas constitucionais, visto que as tarefas foram divididas e não o poder, que é uno e indivisível.

Na esteira dos ensinamentos de Andreas Joachim Krell, conforme lembrado em paradigmática decisão do Supremo Tribunal Federal:

Num sistema político pluralista, as normas constitucionais sobre direitos sociais devem ser abertas para receber diversas concretizações consoante as alternativas periodicamente escolhidas pelo eleitorado. A apreciação dos fatores econômicos para uma tomada de decisão quanto às possibilidades e aos meios de efetivação desses direitos cabe, principalmente, aos governos e parlamentos. Em princípio, o Poder Judiciário não deve intervir em esfera reservada a outro Poder para substituí-lo em juízos de conveniência e oportunidade, querendo controlar as opções legislativas de organização e prestação, a não ser, excepcionalmente, quando haja uma violação evidente e arbitrária, pelo legislador, da incumbência constitucional. No entanto, parece-nos cada vez mais necessária a revisão do vetusto dogma da Separação dos Poderes em relação ao controle dos gastos públicos e da prestação dos serviços básicos no Estado Social, visto que os Poderes Legislativo e Executivo no Brasil se mostraram incapazes de garantir um cumprimento racional dos respectivos preceitos constitucionais. (grifo nosso) ${ }^{118}$

O Poder Judiciário pode exercer relevante papel na efetividade dos direitos fundamentais sociais, consolidando dessa forma o mandamento constitucional de proteger e promover os direitos fundamentais, muitas vezes negligenciados pelos poderes políticos, o Legislativo e o Executivo.

Nesse sentido, cumpre salientar que resta à população como alternativa a reivindicação de tais direitos pela via judicial, em geral, através de Ação Civil Pública, impetrada pelo Ministério Público. Neste diapasão, vale destacar a seguinte decisão:

O caráter programático da regra inscrita no art. 196 da Carta Política que tem por destinatários todos os entes políticos que compõem, no plano institucional, a organização federativa do Estado brasileiro não pode converter-se em promessa constitucional inconseqüente, sob pena de o Poder Público, fraudando justas expectativas

118 STF, ADPF n. 45 MC/DF- Medida Cautelar em ADPF, j. 29/04/2004. Disponível em: <http://www.stf.jus.br/ portal/jurisprudencia/listarJurisprudencia.asp?s l=45.NUME.\&base=baseMonocraticas $>$ Acesso em: 9 jul. 2010. 
nele depositadas pela coletividade, substituir, de maneira ilegítima, o cumprimento de seu impostergável dever, por um gesto irresponsável de infidelidade governamental ao que determina a própria Lei Fundamental do Estado. Distribuição gratuita de medicamentos a pessoas carentes. O reconhecimento judicial da validade jurídica de programas de distribuição gratuita de medicamentos a pessoas carentes, inclusive àquelas portadoras do vírus HIV/AIDS, dá efetividade a preceitos fundamentais da Constituição da República (arts. $5^{\circ}$, caput, e 196) e representa, na concreção do seu alcance, um gesto reverente e solidário de apreço à vida e à saúde das pessoas, especialmente daquelas que nada têm e nada possuem, a não ser a consciência de sua própria humanidade e de sua essencial dignidade. Precedentes do $\mathrm{STF}^{119}$ (grifo nosso)

Saliente-se que neste julgado supramencionado, o Ministro defende que o uiz não deve se preocupar com a falta de previsão orçamentária, problema a ser solucionado selo administrador, a quem compete atender, de modo equilibrado, as necessidades tos cidadãos, especialmente daqueles mais necessitados e doentes. Ademais, pode-se inferir que o Poder Público é quem deve velar, de modo responsável, pela formulação 乏 implementação de políticas sociais e econômicas idôneas que visem a garantir aos zidadãos o acesso universal e igualitário à assistência farmacêutica e médico-hospitalar. ${ }^{120}$

\subsection{Aplicação da reserva do possível: seus limites}

No âmbito da temática da reserva do possível, comporta o tenso debate xcerca dos limites necessários à sua aplicação, bem como o ônus argumentativo do Poder

19 STF, Agravo Regimental em RE 271.286/RS - Agravo Regimental em RE, cujo Relator foi o Ministro Celso de Mello, DJ 24/11/2000, em que enfatiza: "O direito público subjetivo à saúde representa prerrogativa jurídica indisponível assegurada à generalidade das pessoas pela própria Constituição da República (art. 196). Traduz bem jurídico constitucionalmente tutelado, por cuja integridade deve velar, de maneira responsável, o Poder Público, a quem incumbe formular - e implementar - políticas sociais e econômicas idôneas que visem a garantir, aos cidadãos, inclusive àqueles portadores do vírus HIV, o acesso universal e igualitário à assistência farmacêutica e médico-hospitalar. O direito à saúde além de qualificar-se como direito fundamental que assiste a todas as pessoas - representa conseqüência constitucional indissociável do direito à vida. O Poder Público, qualquer que seja a esfera institucional de sua atuação no plano da organização federativa brasileira, não pode mostrar-se indiferente ao problema da saúde da população, sob pena de incidir, ainda que por censurável omissão, em grave comportamento inconstitucional. A interpretação da norma programática não pode transformá-la em promessa constitucional inconseqüente." Disponível em: <http://www.jusbrasil.com.br/filedown/dev0/files/JUS2/STF/TT/RE-AGR_271286_RS\%20_12.09.2000. pdf $>$. Acesso em: 20 set. 2010.

20 STF, Agravo Regimental em RE 271.286/RS, Rel. Ministro Celso de Mello, DJ 24/11/2000. Disponível em $<$ http://www.jusbrasil.com.br/filedown/dev0/files/JUS2/STF/IT/RE-AGR_271286_RS\%20_12.09.2000.pdf> Acesso em: 20 set. 2010. 
Público, ao alegar tal argumento como restrição a determinado direito fundamental social prestacional.

Conforme julgado do Superior Tribunal de Justiça, a tese da reserva do possível:

\begin{abstract}
(...) assenta-se em idéia que, desde os romanos, está incorporada na tradição ocidental, no sentido de que a obrigação impossível não pode ser exigida (Impossibilium nulla obligatio est Celso, D. 50, 17, 185). Por tal motivo, a insuficiência de recursos orçamentários não pode ser considerada uma mera falácia. Todavia, observase que a dimensão fática da reserva do possível é questão intrinsecamente vinculada ao problema da escassez. Esta pode ser compreendida como "sinônimo" de desigualdade. 121
\end{abstract}

Tal alegação deve ser rigorosamente apurada, investigada, avaliada pelo magistrado, no momento de sopesar interesses, bens, valores jurídicos em tela em determinada demanda ligada a direito social.

À guisa de ilustração, cabível trazer à colação a seguinte decisão do Superior Tribunal de Justiça: "É por esse motivo que, em um primeiro momento, a reserva do possível não pode ser oposta à efetivação dos Direitos Fundamentais, já que, quanto a estes, não cabe ao administrador público preteri-los em suas escolhas", 122

Todavia, observa-se, na esteira da lição exarada em recente Recurso Especial, cujo relator foi o Ministro Humberto Martins, no qual assevera que a reserva do possível está vinculada à escassez, que pode ser compreendida como desigualdade. Bens escassos não podem ser usufruídos por todos e, justamente por isso, sua distribuição faz-se mediante regras que pressupõem o direito igual ao bem e a impossibilidade do uso igual e simultâneo ${ }^{123}$

Essa escassez, muitas vezes, é resultado de escolha, de decisão: quando não há recursos suficientes, a decisão do administrador de investir em determinada área implica escassez de outra que não foi contemplada.

121 STJ, REsp n. 1.185.474-SC, cuja relatoria é do Min. Humberto Martins, j. 20/04/2010. Disponível em: $<$ http://www.stj.jus.br/SCON/jurisprudencia/toc.jsp>. Acesso em: 20 set. 2010.

122 STJ, REsp n. 1.185.474 - SC, cuja relatoria é do Min. Humberto Martins, j. 20/04/2010. Só haverá democracia real onde houver liberdade de expressão, pluralismo político, acesso à informação, à educação, inviolabilidade da intimidade, o respeito às minorias e às ideias minoritárias etc. Tais valores não podem ser malferidos, ainda que seja a vontade da maioria. Caso contrário, se estará usando da "democracia" para extinguir a Democracia. Disponível em: $<\mathrm{http} / /$ www.stj.jus.br/SCON/jurisprudencia/toc.jsp $>$. Acesso em: 20 set. 2010.

123 STJ, REsp n. 1.185.474-SC, cuja relatoria é do Min. Humberto Martins, j. 20/04/2010. Disponível em: $<$ http://www.stj.jus.br/SCON/jurisprudencia/toc.jsp>. Acesso em: 20 set. 2010. 
Por esse motivo, em um primeiro momento, a reserva do possível não pode ser oposta à efetivação dos direitos fundamentais, já que não cabe ao administrador público preteri-la, visto que não é opção do governante, não é resultado de juízo discricionário, nem pode ser encarada como tema que depende unicamente da vontade política. Nem mesmo a vontade da maioria pode tratar tais direitos como secundários. Isso porque a democracia é, além dessa vontade, a realização dos direitos fundamentais. ${ }^{124}$

Em um momento, o juiz, para acolher o argumento da reserva do possível deve verificar primeiro dados fáticos da realidade, como a escassez de recursos e de forma imprescindível como foram alocados os recursos disponíveis. Destarte, a rejeição, a negação à prestação de direito social não deve ser aceita de modo automático. Conforme leciona Marcelo Rebello Pinheiro, a alegação da reserva do possível deve ser rigorosamente verificada, apurada, quando o magistrado fizer o exame das circunstâncias do caso concreto. ${ }^{125}$

Somente se a escassez for absoluta é que o juiz deve aceitar o argumento da reserva do possível, segundo o autor supramencionado. E neste contexto, impende realçar, por oportuno, que o ônus de comprovar, demonstrar objetivamente a escassez é do Poder Publico, que não poderá apenas alegar tal empecilho à efetivação de direitos fundamentais sociais sem suporte probatório. ${ }^{126}$

De outro ângulo, se a escassez for relativa, deve-se verificar se a finalidade para a qual se aplicou o dinheiro, o recurso público é prioridade constitucional, ou seja, sem olvidar que tal averiguação, perquirição sempre deverá ser feita à luz da Constituição. ${ }^{127}$

No processo de efetivação de um direito fundamental social, conforme ADPF 45/DF, o Ministro Celso de Mello refere-se à análise do judiciário acerca do binômio razoabilidade da pretensão mais disponibilidade financeira do Estado, cumulativamente, no processo decisional com o fito de conceder ou não determinada prestação, objeto de direito social. As palavras do Ministro do Supremo:

Vê-se, pois, que os condicionamentos impostos, pela cláusula
da "reserva do possível", ao processo de concretização dos
direitos de segunda geração de implantação sempre
onerosa -, traduzem-se em um binômio que compreende, de
"um lado, (1) a razoabilidade da pretensão individual/social
deduzida em face do Poder Público e, de outro, (2)a existência
de disponibilidade financeira do Estado para tornar efetivas

124 STJ, Resp n. 1.185.474-SC, j. 20/04/2010, cuja relatoria é do Min. Humberto Martins. Disponível em: $<\mathrm{http}: / /$ www.stj.jus.br/SCON/jurisprudencia/toc.jsp>. Acesso em: 20 set. 2010.

125 PINHEIRO, Marcelo Rebello. A eficácia e a efetividade dos direitos sociais de caráter prestacionais: em busca da superação dos obstáculos. Dissertação apresentada na UnB, 2008. Disponível em: <http://bdtd. bce.unb.br/tedesimplificado/tde_busca/arquivo.php?codArquivo=3646>. Acesso em: 16 jul. 2010. Id. Ibid.

127 Id. Ibid. 
as prestações positivas dele reclamadas. Desnecessário acentuar-se, considerado o encargo governamental de tornar efetiva a aplicação dos direitos econômicos, sociais e culturais, que os elementos componentes do mencionado binômio (razoabilidade da pretensão + disponibilidade financeira do Estado) devem configurar-se de modo afirmativo e em situação de cumulativa ocorrência, pois, ausente qualquer desses elementos, descaracterizar-se-á a possibilidade estatal de realização prática de tais direitos. ${ }^{128}$ (grifo nosso)

Em um segundo momento, como assevera Ana Carolina Lopes Olsen sobre a teoria do núcleo ou conteúdo essencial dos direitos fundamentais:

(...) é preciso fazer uma ressalva no sentido de que mesmo com a alocação dos recursos no atendimento do mínimo existencial persista a carência orçamentária para atender a todas as demandas. ${ }^{129}$

Mesmo quando há eficiente alocação dos recursos, atendendo-se ao mínimo existencial, ainda assim o orçamento não consegue abarcar todas as demandas sociais, e alerta Ana Carolina Olsen:

Nesse caso, a escassez não seria fruto da escolha de atividades não prioritárias, mas sim da real insuficiência orçamentária. Em situações limítrofes como essa, não há como o Poder Judiciário imiscuir-se nos planos governamentais, pois estes, dentro do que é possível, estão de acordo com a Constituição, não havendo omissão injustificável. ${ }^{130}$

Daí a importância do estabelecimento das prioridades ao elaborar o plano plurianual, bem como a lei orçamentária, para que o executivo possa implementar as políticas sociais também de maneira eficiente.

O constitucionalista Luís Roberto Barroso assevera:

Os direitos fundamentais incluem: a) a liberdade, isto é, a autonomia da vontade, o direito de cada um eleger seus projetos existenciais; b) a igualdade, que é o direito de ser tratado com a mesma dignidade que todas as pessoas, sem discriminações arbitrárias e exclusões evitáveis; c) o mínimo existencial, que corresponde às condições elementares de educação, saúde e renda que permitam, em uma determinada sociedade, o acesso aos valores civilizatórios e a participação

128 STF, ADPF n. 45 MC/DF- Medida Cautelar em ADPF; j. 29/04/2004. Disponivel em: <http://www.stf.jus. $\mathrm{br} /$ portal/jurisprudencia/listarJurisprudencia.asp?s1=45.NUME.\&base=baseMonocraticas $>$ Acesso em: 09 jul. 2010.

129 OLSEN, Ana Carolina Lopes. A eficácia dos direitos fundamentais sociais frente à reserva do possível. cit.

130 Id. Ibid. 
esclarecida no processo político e no debate público. Os três Poderes - Legislativo, Executivo e Judiciário - têm o dever de realizar os direitos fundamentais, na maior extensão possível, tendo como limite mínimo o núcleo essencial desses direitos. ${ }^{131}$

Por derradeiro, convém mencionar a teoria que defende a aplicação do princípio da proporcionalidade (adequação, necessidade e proporcionalidade stricto sensu, esta última que consiste na ponderação), como parâmetro no processo de sopesamento entre os interesses, valores e bens jurídicos em colisão, mediante as peculiaridades do caso concreto.

\subsubsection{O princípio do mínimo existencial}

Frise-se, na perspectiva atinente à teoria do mínimo existencial a imposição de que os direitos fundamentais previstos no texto constitucional devem ter o mínimo de aplicabilidade prática, de existência, de efetivação.

Em que pese já salientado em tópico anterior, o núcleo consubstanciador do mínimo existencial é intangível, deve ser preservado do âmbito discricionário do arbítrio estatal, conforme preleciona o Ministro Celso de Mello na decisão monocrática, referência maior quando se trata da aplicação da reserva do possível, no que concerne à problemática de efetivação dos direitos sociais. ${ }^{132}$

O professor Fernando Facury Scaff observa que:

O mínimo existencial não é uma categoria universal. Varia de lugar para lugar, mesmo dentro de um mesmo país. É a combinação de capacidades para o exercício de liberdades políticas, civis, econômicas e culturais que determinará este patamar de mínimo existencial. Não são apenas os aspectos econômicos os principais envolvidos. "A expansão dos serviços de saúde, educação, seguridade social, etc. contribui diretamente para a qualidade da vida e seu florescimento. Há evidências até de que, mesmo com renda relativamente baixa, um país que garante serviços de saúde e educação a todos pode efetivamente obter resultados notáveis de duração e qualidade de vida de toda a população". O status positivus libertatis está vinculado à efetividade do exercício das capacidades que podem permitir ao ser humano alcançar

131 BARROSO Luís Roberto. Da falta de efetividade à judicialização excessiva: direito à saúde, fornecimento gratuito de medicamentos e parâmetros para a atuação judicial. Disponível em: <www.lrbarroso.com.br/pt/ noticias/medicamentos.pdf $>$. Acesso em: 22 set. 2010.

132 STF, $A D P F$ n. 45 MC/DF- Medida Cautelar em ADPF, j. 29/04/2004. Disponivel em: <http://www.stf.jus. $\mathrm{br}$ /portal/jurisprudencia/listarJurisprudencia.asp?s I=45.NUME.\&base=baseMonocraticas $>$. Acesso em: 09 jul. 2010. 
o desenvolvimento, sejam estas políticas, civis, econômicas ou culturais. ${ }^{133}$

O Supremo Tribunal Federal tem se posicionado favoravelmente à efetivação dos direitos fundamentais sociais, superando a reserva do possível, desde que a prestação pleiteada seja vinculada ao mínimo existencial. À guisa de exemplo, vale transcrever trecho da seguinte decisão:

A questão da legitimidade constitucional do controle e da intervenção do Poder Judiciário em tema de implementação de políticas públicas, quando configurada hipótese de abusividade governamental. dimensão política da jurisdição constitucional atribuída ao Supremo Tribunal Federal. inoponibilidade do arbítrio estatal à efetivação dos direitos sociais, econômicos e culturais. caráter relativo da liberdade de conformação do legislador. considerações em torno da cláusula da "reserva do possível". Necessidade de preservação, em favor dos indivíduos, da integridade e da intangibilidade do núcleo consubstanciador do "mínimo existencial" Viabilidade instrumental da argüição de descumprimento no processo de concretização das liberdades positivas (direitos constitucionais de segunda geração). ${ }^{134}$ (grifo nosso)

Note-se que na ADPF 45/DF, acima referida, é enfatizado: “O mínimo existencial, como se vê, associado ao estabelecimento de prioridades orçamentárias, é capaz de conviver produtivamente com a reserva do possível" 135

No mesmo sentido, extraído da paradigmática decisão ADPF 45/DF, o Ministro Celso de Mello adverte:

(...) a cláusula da "reserva do possível" - ressalvada a ocorrência de justo motivo objetivamente aferível - não pode ser invocada, pelo Estado, com a finalidade de exonerarse do cumprimento de suas obrigações constitucionais, notadamente quando, dessa conduta governamental negativa, puder resultar nulificação ou, até mesmo, aniquilação de direitos constitucionais impregnados de um sentido de essencial fundamentalidade. Daí a correta ponderação de Ana Paula de Barcellos ("A eficácia jurídica dos princípios

133 SCAFF, Fernando Facury. Reserva do possível, mínimoexistencial e direitos humanos. Revista Interesse Público, n. 32, p. 213-226, 2005. Disponível em: <http://www.scaff.adv.br/cgi-bin/lista_doc.cgi?id_usuario $=1000001 \& u=1000000 \& d=19 \& d t=20080512 \& c=0 \& f l \_$backup $=0 \&$ data_backup $=($ null $)$. Acesso em: 9 ago. 2010.

134 STF, ADPF n. 45 MC/DF- Medida Cautelar em ADPF, j. 29/04/2004. Disponivel em: <http://www.stf.jus. $\mathrm{br} /$ portal/jurisprudencia/listarJurisprudencia.asp?sl=45.NUME.\&base=baseMonocraticas $>$. Acesso em: 9 jul. 2010.

135 Id. Ibid. 
constitucionais", p. 245-246, 2002, Renovar): "Em resumo: a limitação de recursos existe e é uma contingência que não se pode ignorar. $\mathrm{O}$ intérprete deverá levá-la em conta ao afirmar que algum bem pode ser exigido judicialmente, assim como o magistrado, ao determinar seu fornecimento pelo Estado. Por outro lado, não se pode esquecer que a finalidade do Estado ao obter recursos, para, em seguida, gastá-los sob a forma de obras, prestação de serviços, ou qualquer outra política pública, é exatamente realizar os objetivos fundamentais da Constituição. ${ }^{136}$

O juiz federal George Marmelstein Lima critica a teoria do mínimo existencial, por vislumbrar na garantia deste mínimo social incompatibilidade com a realidade brasileira, bem como pelo receio de que tal posicionamento, no contexto da exegese de um caso concreto, possa neutralizar os direitos fundamentais sociais consagrados na Constituição Federal. ${ }^{137}$

No entanto, há julgados, como a Suspensão da Tutela Antecipada n. - STA 238-TO, em que o Ministro da Suprema Corte, Gilmar Mendes, manifestou-se acerca do assunto em tela e assim consignou:

(...) ante a impreterível necessidade de ponderações, são as circunstâncias específicas de cada caso que serão decisivas para a solução da controvérsia. Há que se partir, de toda forma, do texto constitucional e de como ele consagra o direito fundamental à saúde. ${ }^{138}$

Segundo o juiz federal George Marmelstein, o núcleo essencial do direito fundamental social deve ser ampliado ao máximo, de tal sorte que não se reduza a concepção

136 Nesse mesmo sentido, adverte ainda o Ministro Celso de Mello: "Não obstante a formulação e a execução de políticas públicas dependam de opções políticas a cargo daqueles que, por delegação popular, receberam investidura em mandato eletivo, cumpre reconhecer que não se revela absoluta, nesse domínio, a liberdade de conformação do legislador, nem a de atuação do Poder Executivo. É que, se tais Poderes do Estado agirem de modo irrazoável ou procederem com a clara intenção de neutralizar,comprometendo-a, a eficácia dos direitos sociais, econômicos e culturais, afetando, como decorrência causal de uma injustificável inércia estatal ou de um abusivo comportamento governamental, aquele núcleo intangivel consubstanciador de um conjunto irredutível de condições mínimas necessárias a uma existência digna e essenciais à própria sobrevivência do indivíduo, aí, então, justificar-se-á, como precedentemente já enfatizado - e até mesmo por razões fundadas em um imperativo ético-jurídico -, a possibilidade de intervenção do Poder Judiciário, em ordem a viabilizar, a todos, o acesso aos bens cuja fruição lhes haja sido injustamente recusada pelo Estado."(grifonosso). In: STF, ADPF n. 45 MC/DF-Medida Cautelar em ADPF, j. 29/04/2004. Disponível em: $<$ http://www.stf.jus.br/portal/jurisprudencia/listarJurisprudencia.asp?s1=45.NUME.\&base=baseMonocraticas > Acesso em: 9 jul. 2010.

137 LIMA, George Marmelstein. Efetivação judicial dos direitos econômicos, sociais e culturais. Dissertação apresentada na UFC, 2005. Disponivel em: <http://www.georgemlima.xpg.com.br/dissertacao.pdf $>$. Acesso em: 17 ago. 2010.

138 STF, Suspensão de Tutela Antecipada n. 238-TO, Relator: Min. Gilmar Mendes, j. 21/10/2008. Disponível em: <http://www.stf.jus.br/portal/processo/verProcessoAndamento.asp?incidente=2615256>. Acesso em: 09 set. 2010. 
de mínimo existencial à noção simples do mínimo vital, pois de acordo com suas palavras: "Afinal, se o mínimo existencial fosse apenas o mínimo necessário à sobrevivência, não seria preciso constitucionalizar os direitos sociais, bastando reconhecer o direito à vida" 139

\subsubsection{O princípio da proporcionalidade}

O princípio da proporcionalidade, chamado de princípio da razoabilidade nos EUA, ou da proibição de excesso como preferem os alemães, visa evitar resultados desproporcionais e injustos, quando o magistrado opera o sopesamento dos valores, bens, interesses que se encontrem em contradição. Dessa forma, no caso concreto ter-se-á uma solução mais justa, adequada, razoável.

Nesta linha de raciocínio, cabível assinalar que a doutrina subdivide o princípio da proporcionalidade em três subprincípios: a adequação, a necessidade e a proporcionalidade em sentido estrito. São três elementos de um mesmo princípio.

Segundo o subprincípio da adequação deve haver conformidade entre meios e fins, ou seja, a solução deve ser apropriada para a realização das finalidades. É um requisito que determina que as medidas adotadas mostrem-se aptas a atingir os objetivos pretendidos.

Neste diapasão, vale sublinhar que o segundo subprincípio, da necessidade ou da exigibilidade determina que o direito do cidadão sofra a menor restrição possível. Este pressuposto da necessidade significa que não há nenhum outro meio menos gravoso e eficaz na mesma medida, que possa ser usado para atingir os objetivos pretendidos.

A proporcionalidade em sentido estrito consiste na justa medida, ou seja, na necessidade de ponderação entre os benefícios e prejuízos, que ocorrerão a partir daquela decisão. ${ }^{140}$

Quando se trata de restrições a direitos fundamentais, a doutrina constitucional mais moderna enfatiza que, deve-se verificar se a Constituição Federal admite e também se a restrição é compatível com o princípio da proporcionalidade. ${ }^{141}$

Consoante os ensinamentos do Ministro do Supremo Tribunal Federal Gilmar Mendes na Suspensão de Tutela Antecipada n. 238/TO, julgada em 2008:

139 LIMA, George Marmelstein. Mínimo existencial, reserva do possível e direito à saúde. Disponivel em: $<\mathrm{http} / /$ direitosfundamentais.net/2008/10/27/minimo-existencial-reserva-do-possível-e-direito-a-saude/>. Acesso em: 4 mar. 2010.

140 COSTA, Alexandre Araújo. O controle da razoabilidade no direito comparado. Disponível em: <http:// www.arcos.org.br/livros/o-controle-da-razoabilidade-no-direito-comparado/capitulo-iii/a-definicao-doprincipio-da-proporcionalidade/l-elementos-do-principio-da-proporcionalidade>. Acesso em: 8 ago. 2010 .

14) STF, Suspensão de Tutela Antecipada n. 238-TO, Relator: Ministro Gilmar Mendes, j. 21/10/2008. Disponivel em: <http://www.stf.jus.br/portal/processo/verProcessoAndamento.asp?incidente $=2615256>$. Acesso em: 9 set. 2010. 
As divergências doutrinárias quanto ao efetivo âmbito de proteção da norma constitucional do direito à saúde decorrem, especialmente, da natureza prestacional desse direito e da necessidade de compatibilização do que se convencionou denominar de "mínimo existencial" e da "reserva do possível" (Vorbehalt des Möglichen). Como tenho analisado em estudos doutrinários, os direitos fundamentais não contêm apenas uma proibição de intervenção, expressando também um postulado de proteção. Haveria, assim, para utilizar uma expressão de Canaris, não apenas uma proibição de excesso, mas também uma proibição de proteção insuficiente (...)... ${ }^{142}$

$\mathrm{Na}$ aplicação do princípio da proporcionalidade, assume-se relevância determinante a ponderação entre os fins e os meios, permitindo uma interpretação de forma variada na aplicação no caso concreto. ${ }^{143}$

Cumpre frisar que a aplicação do princípio da proporcionalidade repousa, na necessidade de interpretar-se a norma positivada com coerência, harmonizando, sempre que possível, os vários interesses antagônicos que formam uma mesma relação jurídica. Pois quando ocorre uma colisão de princípios necessário averiguar qual deles possui maior peso, diante das singularidades do caso concreto, dependendo portanto do processo de ponderação.

O postulado da proporcionalidade implica uma adequação axiológica e finalística, teleológica pelo agente público. Há que atentar para o seu poder-dever de hierarquizar princípios e valores de maneira adequada na atividade administrativa. $\mathrm{O}$ princípio da proporcionalidade determina que um meio - nesse caso a política pública - deve ser adequado, necessário e não deve ficar sem relação de proporcionalidade relativamente ao fim instituído pela norma. Portanto, o dever de proporcionalidade deve ter sua aplicação mediante critérios racionais e intersubjetivamente controláveis. ${ }^{144}$

Leciona José Reinaldo de Lima Lopes:

Esta é a encruzilhada do Judiciário de um Estado de Direito e Social: garantir as regras do jogo, mas de um jogo que sirva para ampliar liberdade e igualdade. Isto não significa desfazer-se do valor da democracia, mas recuperar sua dignidade como melhor regime possível para realizar o bem

142 STF, Suspensão de Tutela Antecipada n. 238-TO, Relator: Min. Gilmar Mendes, j. 21/10/2008. Disponível $\mathrm{em}:<\mathrm{http}: / /$ www.stf.jus.br/portal/processo/verProcessoAndamento.asp?incidente $=2615256>$. Acesso em: 9 set. 2010.

143 SILVA, Roberta Pappen da. Algumas considerações sobre o principio da proporcionalidade. Disponivel em: $<$ http://jus2.uol.com.br/doutrina/texto.asp?id=6198>. Acesso em: 8 ago. 2010.

144 SILVA, Roberta Pappen da. Algumas considerações sobre o princípio da proporcionalidade. Disponível em: $<$ http://jus2.uol.com.br/doutrina/texto.asp?id=6198>. Acesso em: 9 set. 2010. 
comum, que não se distingue de uma vida humana digna, livre e acessível a qualquer um do povo. ${ }^{145}$

Os direitos fundamentais sociais, conforme ensina George Marmelstein: "não são um acessório supérfluo que apenas os países ricos podem se dar ao luxo de fornecer. São, pelo contrário, uma alavanca de desenvolvimento" ${ }^{146}$ Portanto, a efetivação de tais direitos deve ser levada a sério, sob pena do Brasil jamais alcançar sua meta de superar as desigualdades sociais e ser de fato um Estado pautado pela justiça social.

Conclusão

No desenvolver deste trabalho, percebeu-se que a temática da efetivação dos direitos fundamentais sociais, alvo de vários debates no cenário nacional e internacional, gira em torno de questões de cunho jurídico, econômico, dentre outras.

Vale ressaltar que, diante das considerações explicitadas neste trabalho, verificou-se que é possível a intervenção do Poder Judiciário na seara de políticas públicas sempre que houver omissão, falha, negligência dos poderes políticos, ainda que em caráter excepcional. A atuação do Judiciário de forma imediata e direta, concedendo prestações materiais de cunho social urge na situação em que os poderes eleitos pelo voto popular - Legislativo e Executivo contrariar ou negligenciar, por ação ou omissão, o núcleo essencial dos direitos fundamentais, os quais representam o cerne da Lei Maior do país, a Constituição de 1988.

Todavia, há carência de postulados mais consistentes, que ofereçam uma direção mais clara na interpretação das normas que definem os direitos fundamentais sociais. É imprescindível o atendimento das prioridades constitucionais, que leve em consideração as necessidades das pessoas, em consonância com a promoção da dignidade da pessoa humana e, de outro lado, nota-se a necessidade de um sopesamento que considere a realidade, a conjuntura social brasileira, visto como pano de fundo haver a inegável escassez de recursos.

Observou-se que a realização do Estado Democrático de Direito e, consequentemente a efetivação dos direitos fundamentais é obrigação de todos os poderes do Estado. Portanto, se algum dos poderes - cuja representação advinda de voto popular - não desempenhar a contento seu papel, conforme os ditames prescritos na

145 LOPES, José Reinaldo de Lima. Direito subjetivo e direitos sociais: o dilema do Judiciário no Estado Social de Direito. In: FARIA, José Eduardo. Direitos humanos, direitos sociais e justiça. 1 ed. 3 tir. São Paulo: Malheiros, 2002. p. 142.

146 LIMA, George Marmelstein. Efetivação judicial dos direitos econômicos, sociais e culturais. Dissertação apresentada na UFC, 2005. Disponível em: <http://www.georgemlima.xpg.com.br/dissertacao.pdf $>$. Acesso em: 17 ago. 2010. 
Constituição Federal, falhando em seu mister constitucional, cabe aos demais poderes suprir tal deficiência, de modo que a sociedade não tenha que ficar sem a política pública adequada, necessária e viável tendo em vista a disponibilidade e correta alocação dos recursos público, bem como a razoabilidade da pretensão pleiteada. Só assim a democracia realmente atingirá seus fins precípuos, no contexto de um Estado Democrático e Social de Direito.

São Paulo, dezembro de 2010.

\section{Referências}

ALMEIDA JÚNIOR, Elmo José Duarte de. Aspectos relevantes dos direitos sociais de prestação frente ao minimo existencial e à reserva possivel. Disponível em: <http://jus2.uol.com.br/doutrina/ texto.asp?id=10357>. Acesso em: 10 ago. 2010.

ALVES, Sérgio Osborne Moreira. Os direitos fundamentais sociais, "reserva do possivel" e proporcionalidade: desafios à concretização da constituição do estado democrático e social brasileiro. Disponivel em: <http://biblioteca.universia.net/html_bura/ficha/params/id/41432060.html>. Acesso em: 10 set. 2010.

BARROSO Luís Roberto. Da falta de efetividade à judicialização excessiva: direito à saúde, fornecimento gratuito de medicamentos e parâmetros para a atuação judicial. Disponível em: $<$ http:// www.lrbarroso.com.br/pt/noticias/medicamentos.pdf $>$. Acesso em: 22 set. 2010.

BEÇAK, Rubens. A separação dos poderes, o tribunal constitucional e a "judicialização da política". Revista da Faculdade de Direito da Universidade de São Paulo, São Paulo, v.103, jan./dez. 2008.

BUENO, Ewerton Teixeira. Efetividade dos direitos sociais. Revista Internacional Direito e Cidadania. Disponível em: <http://www.iedc.org.br/REID/arquivos/00000093-reid4-04-ewerton.pdf $>$. Acesso em: 18 jul. 2010.

CASTELAR, Armando. Congresso "Direito, politica e economia interseç̧ões e fronteiras no reconhecimento e implementação de direitos" Brasília: Escola Superior do Ministério Público da União, 2010. Disponível em: <http://www3.esmpu.gov.br/material-didatico/degravac327a303o congresso poli301 tica.pdf $>$. Acesso em: 14 jun. 2010.

CLÈVE, Clèmerson Merlin. A eficácia dos direitos sociais. Revista de Direito Constitucional e Internacional, São Paulo, ano 14, n. 54, jan./mar. 2006.

COSTA, Alexandre Araújo. O controle da razoabilidade no direito comparado. Disponível em: $<$ http://www.arcos.org.br/livros/o-controle-da-razoabilidade-no-direito-comparado/capitulo-iii/adefinicao-do-principio-da-proporcionalidade/1-elementos-do-principio-da-proporcionalidade $>$ Acesso em: 08 ago. 2010.

FARIA, José Eduardo (Org.). O Judiciário e os direitos humanos e sociais. São Paulo: Malheiros, 2002. 
FARIA, LuizAlberto Gurgel de Faria. Direitos sociais: positivação X eficácia. Disponível em: $<$ http:// www.buscalegis.ufsc.br/revistas/index.php/buscalegis/article/viewFile/15592/15156> Acesso em: 14 ago. 2010.

FERRAZ, Sérgio. Degravação do Congresso "Direito, política e economia - intersecções e fronteiras no reconhecimento e implementação de direitos", 2010. Disponível em: <http://www3.esmpu.gov.br/ material-didatico/degravac327a303o_congresso_poli301tica.pdf>. Acesso em: 14 jun. 2010.

LEIVAS, Paulo Gilberto Cogo. Princípios de direito e de justiça na distribuição de recursos escassos. Revista Bioética, v. 14, n. 1, 2007. Disponível em: <http://www.portalmedico.org.br/revista/ bio14v1/artigos01.htm>. Acesso em: 08 ago. 2010.

LEWANDOWSKI, Enrique Ricardo. A formação da doutrina dos direitos fundamentais. Revista da Faculdade de Direito da Universidade de São Paulo, São Paulo, v. 98, p. 411-422, 2003.

LIMA, George Marmelstein. Efetivação judicial dos direitos econômicos, sociais e culturais. Dissertação apresentada na UFC, 2005. Disponível em: <http://www.georgemlima.xpg.com.br/ dissertacao.pdf $>$. Acesso em: 17 ago 2010.

. LIMA, George Marmelstein. Direitos fundamentais e frustração constitucional. Disponível

em: <http://direitosfundamentais.net/2007/08/13/direitos-fundamentais-e-frustracao-constitucional/>. Acesso em: 13 ago 2010.

LOPES, José Reinaldo de Lima. Direito subjetivo e direitos sociais: o dilema do Judiciário no Estado Social de Direito. In: FARIA, José Eduardo (Org.). Direitos humanos, direitos sociais e justiça. São Paulo: Malheiros, 2002.

OLSEN, Ana Carolina Lopes. A eficácia dos direitos fundamentais sociais frente à reserva do possivel. Dissertação apresentada na UFPR, 2006. Disponível em: <http://dspace.c3sl.ufpr.br/ dspace/bitstream/1884/3084/1/Disserta\%C3\%A7\%C3\%A30\%20\%20Ana\%20Carolina\%20 Lopes\%20Olsen.pdf $>$. Acesso em: 20 set. 2010.

PESSANHA, Érica. A eficácia dos direitos sociais prestacionais. Revista da Faculdade de Direito de Campos, Ano 7, n. 8, jun. 2006. Disponível <http://bdjur.stj.gov.br/xmlui/handle/2011/24792>. Acesso em: 04 jul. 2010.

PINHEIRO, Marcelo Rebello. A eficácia e a efetividade dos direitos sociais de caráter prestacionais: em busca da superação dos obstáculos. Dissertação apresentada na UnB, 2008. Disponível em: $<$ http://bdtd.bce.unb.br/tedesimplificado/tde_busca/arquivo.php?codArquivo=3646>. Acesso em: 16 jul. 2010.

QUEIROZ, Ari Ferreira. OLIVEIRA, Vitor França Dias. A reserva do possível como parâmetro de sindicância dos direitos fundamentais sociais. Disponível em: <http://www.revistas.ufg.br/index. php/revfd/article/viewPDFInterstitial/9799/6691>. Acesso em: 08 ago. 2010. 
ROCHA, Rosalia Kappel. A eficácia dos direitos sociais e a reserva do possível. Disponível em: $<$ http://www.escola.agu.gov.br/revista/Ano_V_novembro_2005/rosalia-eficacia.pdf $>$. Acesso em: 10 set. 2010 .

ROSA, Marizélia Peglow da; GORCZEVSKI, Clovis. A concretização dos direitos humanos sociais e a reserva do possível. Disponível em: <http://www.conpedi.org.br/manaus/arquivos/anais/ salvador/marizeli_peglow_da_rosa.pdf $>$. Acesso em: 08 ago. 2010.

SARLET, Ingo Wolfgang. A dignidade da pessoa humana e os direitos fundamentais na Constituição de 1988. Porto Alegre: Livraria do advogado, 2001.

A eficácia dos direitos fundamentais. 3. ed. rev. e atual. Porto Alegre: Livraria do Advogado, 2001.

Algumas considerações em torno do conteúdo, eficácia e efetividade do direito à saúde na constituição de 1988. Disponível em http://www.buscalegis.ufsc.br/revistas/index.php/buscalegis/ article/viewFile/31953/31199. Acesso em: 06 jul. 2010.

Os direitos fundamentais sociais na Constituição de 1988. Revista Diálogo Jurídico, Salvador, v. 1, n. 1, 2001. Disponível em: <http://www.direitopublico.com.br>. Acesso em 09/09/2010.

Os direitos sociais como direitos fundamentais: contributo para um balanço aos vinte anos da Constituição Federal de 1988. Revista do Instituto de Hermenêutica Jurídica. 20 Anos de Constitucionalismo Democrático. E agora? 2008, p. 163-206. Disponível em: <http://www.stf.jus. br/arquivo/cms/processoAudienciaPublicaSaude/anexo/artigo_Ingo_DF_sociais_PETROPOLIS_ final_01_09_08.pdf>. Acesso em: 07 out. 2010.

FIGUEIREDO, Mariana Filchtiner. Reserva do possível, mínimo existencial e direito à saúde: algumas aproximações. In: SARLET, Ingo Wolfgang; TIMM, Luciano Benetti (Org.). Direitos fundamentais: orçamento e reserva do possível. Porto Alegre: Livraria do Advogado, 2008.

FIGUEIREDO, Mariana Filchtiner. Algumas considerações sobre o direito fundamental à proteção e promoção da saúde aos 20 anos da Constituição Federal de 1988. Disponível em: <ttp:// www.stf.jus.br/arquivo/cms/processoAudienciaPublicaSaude/anexo/O_direito_a_saude_nos_20_ anos_da_CF_coletanea_TAnia_10_04_09.pdf>.Acesso em: 20 ago. 2010.

SARMENTO, Daniel. A dimensão objetiva dos direitos fundamentais: fragmentos de uma teoria. In: SAMPAIO, José Adércio Leite. Jurisdição constitucional e direitos fundamentais. Belo Horizonte: Del Rey, 2003. p. 253.

SCAFF, Fernando Facury. Sentenças aditivas, direitos sociais e reserva do possível. Revista Dialética de Direito Processual. Disponível em: <http://www.scaff.adv.br/cgi-bin/lista_doc.cgi?id_usuario=1 $000001 \& \mathrm{u}=1000000 \& \mathrm{~d}=2 \& \mathrm{dt}=20080508 \& \mathrm{c}=0 \& \mathrm{fl}$ b backup $=0 \&$ data_backup $=($ null $)>$. Acesso em: 18 out. 2010 . 
SCAFF, Fernando Facury. Reserva do possível, mínimo existencial e direitos humanos. In: Interesse Público, ano VII, n. 32, julho/agosto de 2005, p.213-226. Porto Alegre: Notadez. Disponível em: $<$ http://www.scaff.adv.br/cgibin/lista_doc.cgi?id_usuario $=1000001 \& \mathrm{u}=1000000 \& \mathrm{~d}=12 \& \mathrm{dt}=20080$ $512 \& \mathrm{c}=0>$. Acesso em: 9 set. 2010.

SILVA, José Afonso da. Garantias econômicas, políticas e jurídicas da eficácia dos direitos sociais. Disponível em: <http://www.mundojuridico.adv.br>. Acesso em: 20 ago. 2010.

Curso de direito constitucional positivo. 27. ed. rev. e atual. São Paulo: Malheiros, 2006.

SILVA, Roberta Pappen da. Algumas considerações sobre o princípio da proporcionalidade. Disponível em: <http://jus2.uol.com.br/doutrina/texto.asp?id=6198>. Acesso em: 08 ago. 2010.

SILVA, Virgílio Afonso da. O conteúdo essencial dos direitos fundamentais e a eficácia das normas constitucionais. Revista de Direito do Estado, n. 4, p. 23-51, 2006. Disponível em: <http:// teoriaedireitopublico.com.br/pdf/2006-RDE4-Conteudo_essencial.pdf>. Acesso em: 08 ago. 2010.

SOUZA, Luciane Moessa de. Reserva do possível x mínimo existencial: o controle de constitucionalidade em matéria financeira e orçamentária como instrumento de realização dos direitos fundamentais. Disponível em: http://www.conpedi.org.br/manaus/arquivos/anais/bh/ luciane_moessa_de_souza2.pdf>. Acesso em: 05 jul. 2010.

STF, ADPF n. 45 MC/DF- Medida Cautelar em ADPF, j. 29/04/2004. Disponível em: <http://www. stf.jus.br/portal/jurisprudencia/listarJurisprudencia.asp?s l=45.NUME.\&base=baseMonocraticas $>$. Acesso em: 09 jul. 2010.

VAZ, Anderson. A cláusula da reserva do financeiramente possível como instrumento de efetivação planejada dos direitos humanos econômicos, sociais e culturais. Revista de Direito Constitucional e Internacional, ano 17, n. 66, jan./mar. 2009.

WANG, Daniel Wei Liang. Escassez de recursos, custo dos direitos e reserva do possivel na jurisprudência do Supremo Tribunal Federal, 2006. Disponível em: <http://escholarship.org/uc/ item/26q0r0ns>. Acesso em: 20 set. 2010. 